\title{
WASHING AND DEMONSTRATION OF THE DWPF FLOWSHEET IN THE SRNL SHIELDED CELLS USING POST ALUMINUM DISSOLUTION TANK 51 SLUDGE SLURRY
}

J. M. Pareizs

C. J. Bannochie

D. R. Click

E. K. Hansen

D. P. Lambert

M. E. Stone

April 2008

Process Science and Engineering Savannah River National Laboratory Aiken, SC 29808 
WSRC-STI-2008-00086

Revision 0

\section{DISCLAIMER}

This report was prepared by Washington Savannah River Company (WSRC) for the United States Department of Energy under Contract No. DE-AC0996SR18500 and is an account of work performed under that contract. Neither the United States Department of Energy, nor WSRC, nor any of their employees makes any warranty, expressed or implied, or assumes any legal liability or responsibility for the accuracy, completeness, or usefulness, of any information, apparatus, or product or process disclosed herein or represents that its use will not infringe privately owned rights. Reference herein to any specific commercial product, process, or service by trademark, name, manufacturer, or otherwise does not necessarily constitute or imply endorsement, recommendation, or favoring of same by WSRC or by the United States Government or any agency thereof. The views and opinions of the authors expressed herein do not necessarily state or reflect those of the United States Government or any agency thereof.

\section{Printed in the United States of America}

Prepared For

U.S. Department of Energy 
Key Words: DWPF, Sludge, SB5, Washing, Aluminum

Retention: Permanent

\section{WASHING AND DEMONSTRATION OF THE DWPF FLOWSHEET IN THE SRNL SHIELDED CELLS USING POST ALUMINUM DISSOLUTION TANK 51 SLUDGE SLURRY}

J. M. Pareizs

C. J. Bannochie

D. R. Click

E. K. Hansen

D. P. Lambert

M. E. Stone

April 2008

Process Science and Engineering Savannah River National Laboratory Aiken, SC 29808 


\section{REVIEWS AND APPROVALS}

\section{AUTHORS:}

J. M. Pareizs, Process Science \& Engineering

Date

C. J. Bannochie, Process Science \& Engineering

Date

D. R. Click, Analytical Development

Date

E. K. Hansen, Process Science \& Engineering

Date

D. P. Lambert, Process Science \& Engineering

Date

Date

M. E. Stone, Process Science \& Engineering

Date

\section{TECHNICAL REVIEWER:}

S. H. Reboul, Process Science \& Engineering

Date

\section{APPROVERS:}

$\begin{array}{ll}\text { C. C. Herman, Manager, Process Engineering Technology } & \text { Date }\end{array}$

$\overline{\text { J. C. Griffin, Manager, Research Programs, E\&CPT } \quad \text { Date }}$

\begin{tabular}{ll}
\hline J. Stuberfield, Sludge Mass Reduction Project Owner & Date
\end{tabular}

\begin{tabular}{ll}
\hline P. C. Suggs, DOE Waste Disposition Programs, & Date
\end{tabular} 


\section{EXECUTIVE SUMMARY}

The remaining contents of Tank 51 from Sludge Batch 4 will be blended with Purex sludge from Tank 7 to constitute Sludge Batch 5 (SB5). The Savannah River Site (SRS) Liquid Waste Organization (LWO) has completed caustic addition to Tank 51 to perform low temperature Al dissolution on the H-Modified (HM) sludge material to reduce the total mass of sludge solids and Al being fed to the Defense Waste Processing Facility (DWPF). The Savannah River National Lab (SRNL) has also completed aluminum dissolution tests using a 3-L sample of Tank 51 sludge slurry through funding by DOE EM-21.

This report documents assessment of downstream impacts of the aluminum dissolved sludge, which were investigated so technical issues could be identified before the start of SB5 processing. This assessment included washing the aluminum dissolved sludge to a Tank Farm projected sodium concentration and weight percent insoluble solids content and DWPF Chemical Process Cell (CPC) processing using the washed sludge.

Based on the limited testing, the impact of aluminum dissolution on sludge settling is not clear. Settling was not predictable for the 3-L sample. Compared to the post aluminum dissolution sample, settling after the first wash was slower, but settling after the second wash was faster. For example, post aluminum dissolution sludge took six days to settle to $60 \%$ of the original sludge slurry height, while Wash 1 took nearly eight days, and Wash 2 only took two days.

Aluminum dissolution did impact sludge rheology. A comparison between the as-received, post aluminum dissolution and washed samples indicate that the downstream materials were more viscous and the concentration of insoluble solids less than that of the starting material. This increase in viscosity may impact Tank 51 transfers to Tank 40.

The impact of aluminum dissolution on DWPF CPC processing cannot be determined because acid addition for the Sludge Receipt and Adjustment Tank (SRAT) cycle was under-calculated and thus underadded. Although the sludge was rheologically thick throughout the SRAT and Slurry Mix Evaporator (SME) cycles, this may have been due to the under addition of acid.

Aluminum dissolution did, however, impact analyses of the SRAT receipt material. Two methods for determining total base yielded significantly different results. The high hydroxide content and the relatively high soluble aluminum content of the washed post aluminum dissolution sludge likely contributed to this difference and the ultimate under addition of acid. It should be noted that the simulant used to provide input for the SRAT cycle was an inadequate representation of the waste in terms of acid demand, likely due to the differences in the form of aluminum and hydroxide in the simulant and actual waste.

Based on the results of this task, it is recommended that:

- Sludge settling and rheology during washing of the forthcoming Sludge Batch 5 qualification sample be monitored closely and communicated to the Tank Farm.

- $\quad$ SRNL receive a sample of Tank 51 after all chemical additions have been made and prior to the final Sludge Batch 5 decant for rheological assessment. Rheology versus wt\% insoluble solids will be performed to determine the maximum amount of decant prior to the Tank 51 to Tank 40 transfer.

- As a result of the problem with measuring total base and subsequently under-calculating acid for the DWPF CPC processing of the post aluminum dissolution sludge, 
- Studies to develop understanding of how the sludge titrates (i.e., why different titration methods yield different results) should be performed.

- Simulants that better match the properties of post aluminum dissolution sludge should be developed.

Work on developing an acid calculation less dependant on the total base measurement should be continued. 


\section{TABLE OF CONTENTS}

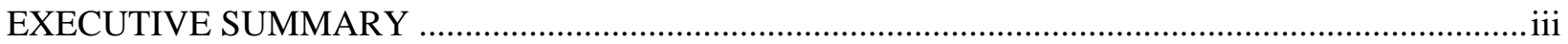

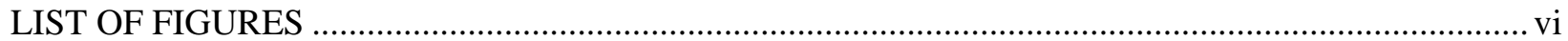

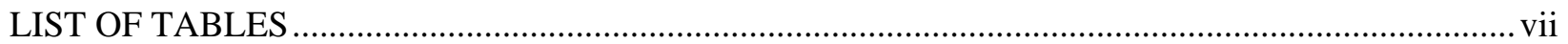

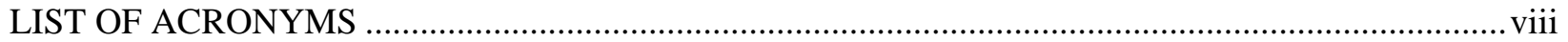

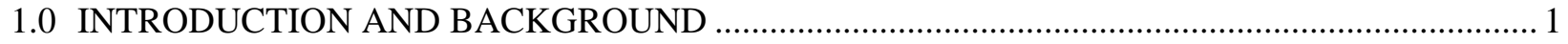

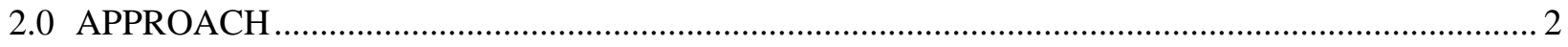

2.1 General Description of Analytical Methods ............................................................................2

2.2 Washing of Post Aluminum Dissolution Tank 51 Sample and Preparation of the SC-4 SRAT

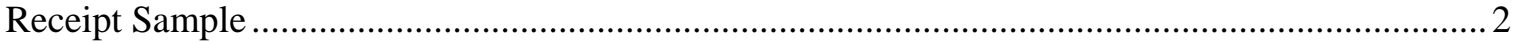

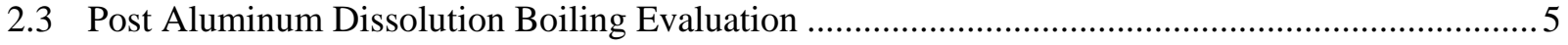

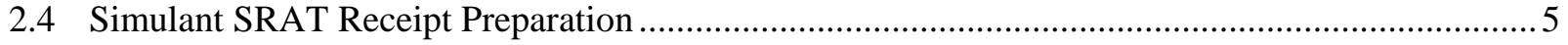

2.5 Chemical Process Cell (CPC) Processing (SRAT Cycle, SME Cycle) ……………………........... 6

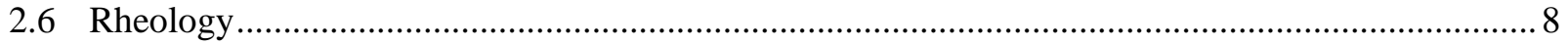

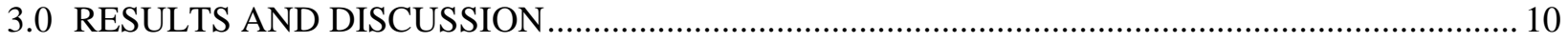

3.1 Washing and SRAT Receipt Preparation................................................................................ 10

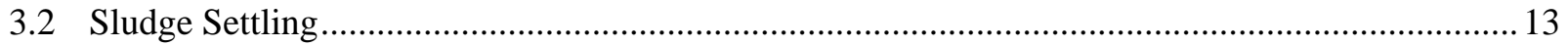

3.3 Results of Boiling the Wash 2/Decant 2a Slurry ……………………………………………........ 14

3.4 SRAT Receipt Characterization and Acid Addition Calculations ………………………………...... 14

3.5 CPC Processing Results......................................................................................................... 17

3.5.1 SRAT Cycle Processing Observations ............................................................................... 17

3.5.2 SRAT Cycle Sample Results...................................................................................... 17

3.5.3 SRAT Cycle Anion Destruction and Conversion.............................................................. 18

3.5.4 SRAT Cycle Offgas Analysis .......................................................................................... 19

3.5.5 SME Processing Observations ……………………………………………………….... 21

3.5.6 SME Cycle Sample Results........................................................................................... 21

3.5.7 SME Cycle Anion Destruction.............................................................................................. 22

3.5.8 SME Cycle Offgas Data ……………………………………………………………. 22

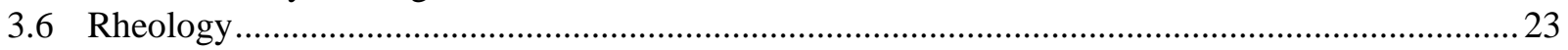

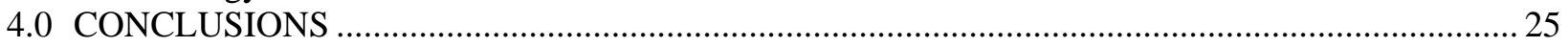

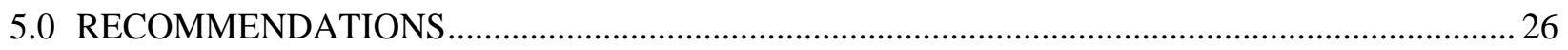

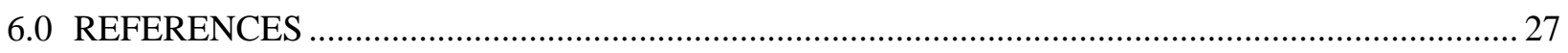

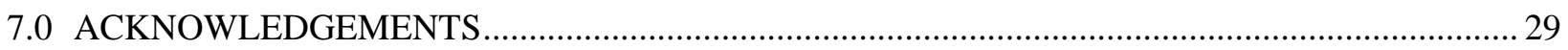

APPENDIX A. SETTLING DATA FROM POST ALUMINUM DISSOLUTION WASHING ................ 30

APPENDIX B. CALCULATION OF ALUMINUM AND SODIUM REMOVAL USING IRON

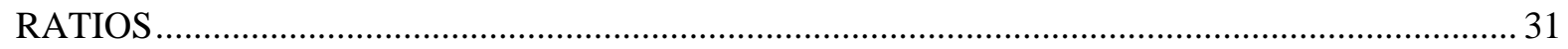

APPENDIX C. RHEOLOGICAL CHARTS AND FLOW CURVES ....................................................... 32

APPENDIX D. HYDROGEN GENERATION FROM THE SIMULANT SRAT CYCLES

SUPPORTING THE POST ALUMINUM DISSOLUTION CPC PROCESSING ………………....... 35 


\section{LIST OF FIGURES}

Figure 2-1. Apparatus for Sludge Boiling Evaluation ............................................................................ 5

Figure 2-2. Schematic of SRAT Equipment Set-Up .......................................................................... 7

Figure 3-1. Sludge Settling During Aluminum Dissolution and Washing .............................................. 14

Figure 3-2. Hydrogen Generation During SC-3 and SC-4 SRAT Cycles.............................................. 20

Figure 3-3. Carbon Dioxide Generation During SC-3 and SC-4 SRAT Cycles ......................................20

Figure 3-4. Nitrous Oxide Generation During SC-3 and SC-4 SRAT Cycles ........................................ 21

Figure 3-5. SME Cycle Hydrogen Generation Data ................................................................................ 23

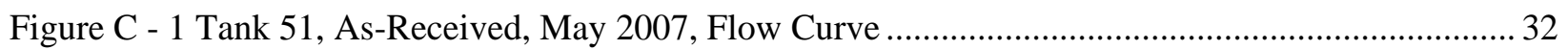

Figure C - 2 Tank 51, SRNL Post Aluminum Dissolution, Flow Curve ................................................. 32

Figure C - 3 Tank 51, SRNL Post Aluminum Dissolution, Wash 1, Flow Curve .................................... 32

Figure C - 4 Tank 51, SRNL Post Aluminum Dissolution, Wash 2a, Flow Curve ................................... 33

Figure C - 5 Tank 51, SRNL Post Aluminum Dissolution, Wash 2b SC-4 SRAT Rcpt, Flow Curve ........ 33

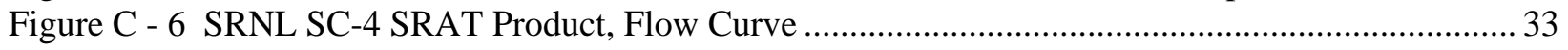

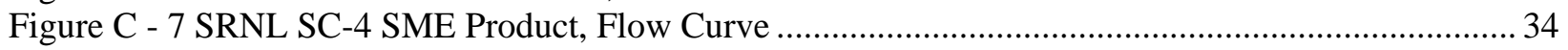

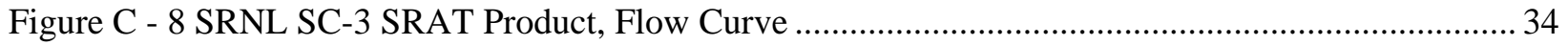

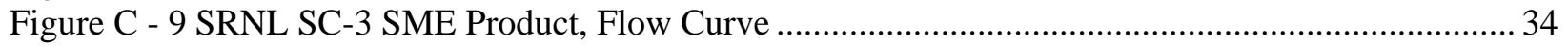




\section{LIST OF TABLES}

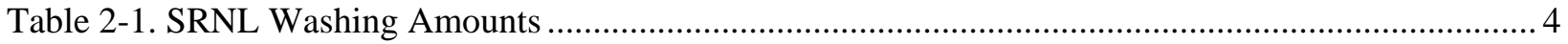

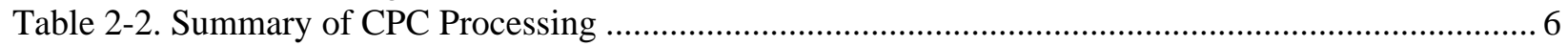

Table 2-3. MV I and MV II Rotor Specifications and Flow Curve Program ............................................ 9

Table 3-1. Weight Percent Solids and Density During Tank 51 Post Aluminum Dissolution Washing .... 10

Table 3-2. Major Components of the Supernate During Washing of the Post Aluminum dissolution Sample 10

Table 3-3. Percentages of Aluminum and Sodium Removed by Dissolution and Washing....................... 11

Table 3-4. Calculated Weight Percent Soluble Aluminum and Sodium.................................................. 11

Table 3-5. Comparison of Major Elements $(>0.1 \%)$ in the Total Solids in the As-Received Tank 51 Sample and the Post Aluminum Dissolution/Washed (SRAT Receipt) Sample ............................... 12

Table 3-6. Comparison of Major Elements in the As-Received Tank 51 Sample and the Post Aluminum Dissolution/Washed (SRAT Receipt) Sample on a Calcined Solids Basis

Table 3-7. Characterization Results and Acid Calculation Inputs of the Post Aluminum Dissolution Tank 51 (SC-4 SRAT Receipt) Sample and the Corresponding Non Rad Simulant SRAT Receipt (SB5-4 \& -5) With Comparison to a Pre Aluminum Dissolution SRAT Receipt (SC-3) Sample ...... 15 Table 3-8. Acid Calculation Inputs of the Washed Post Aluminum Dissolution Tank 51 Sample (SC4 SRAT Receipt) and the Corresponding Non Rad Simulant SRAT Receipt (SB5-4 \& -5) With Comparison to a Pre Aluminum Dissolution SRAT Receipt Sample (SC-3).................................... 16

Table 3-9. SRAT Cycle Acid Requirements....................................................................................... 17

Table 3-10. SRAT Product Characterization Results .................................................................. 18

Table 3-11. Comparison of Assumed and Measured Anion Destruction and Conversion in the SRAT Cycles 18

Table 3-12. SME Product Weight Percent Solids and Densities ........................................................... 22

Table 3-13. Comparison of Assumed and Measured Anion Destruction and Conversion in the SME Cycles

Table 3-14. Rheological Properties of As-Received, Al Dissolved, Washed and SRAT/SME Products... 24 


\section{LIST OF ACRONYMS}

\begin{tabular}{|c|c|}
\hline ACTL & Aiken County Technologies Laboratory \\
\hline $\mathrm{AD}$ & Analytical Development \\
\hline ARG & Analytical Reference Glass \\
\hline ARM & Approved Reference Material \\
\hline ASP & Analytical Study Plan \\
\hline CPC & Chemical Process Cell \\
\hline CS & Calcine Solids \\
\hline DWPF & Defense Waste Processing Facility \\
\hline FAVC & Formic Acid Vent Condenser \\
\hline GC & Gas Chromatograph \\
\hline HLW & High Level Waste \\
\hline HM & H-Modified \\
\hline IC & Ion Chromatography \\
\hline ICP-AES & Inductively Coupled Plasma - Atomic Emission Spectroscopy \\
\hline ICP-MS & Inductively Coupled Plasma - Mass Spectroscopy \\
\hline IS & Insoluble Solids \\
\hline LIMS & Laboratory Information Management System \\
\hline LWO & Liquid Waste Organization \\
\hline MAR & Measurement Acceptability Region \\
\hline MWWT & Mercury Water Wash Tank \\
\hline NIST & National Institute of Standards and Testing \\
\hline PCCS & Product Consistency Control System \\
\hline PMP & Polymethyl propylene \\
\hline PSAL & Process Science Analytical Laboratory \\
\hline PS\&E & Process Science and Engineering Section \\
\hline QA & Quality Assurance \\
\hline REDOX & REDuction / OXidation potential \\
\hline SB4 & Sludge Batch 4 \\
\hline SB5 & Sludge Batch 5 \\
\hline SME & Slurry Mix Evaporator \\
\hline SMECT & Slurry Mix Evaporator Condensate Tank \\
\hline SRAT & Sludge Receipt and Adjustment Tank \\
\hline SRNL & Savannah River National Laboratory \\
\hline SRS & Savannah River Site \\
\hline SS & Soluble Solids \\
\hline TIC & Total Inorganic Carbon \\
\hline TOC & Total Organic Carbon \\
\hline TS & Total Solids \\
\hline TT\&QAP & Task Technical and Quality Assurance Plan \\
\hline TTR & Technical Task Request \\
\hline WAPS & Waste Acceptance Product Specification \\
\hline WL & Waste Loading \\
\hline
\end{tabular}




\subsection{INTRODUCTION AND BACKGROUND}

The current contents of Tank 51 will be blended with Purex sludge from Tank 7 to constitute Sludge Batch 5 (SB5). The Savannah River Site (SRS) Liquid Waste Organization (LWO) has completed caustic addition to Tank 51 to perform low temperature Al dissolution on the H-Modified (HM) sludge material to reduce the total mass of sludge solids and Al being fed to the Defense Waste Processing Facility (DWPF). The Savannah River National Lab (SRNL) has also completed aluminum dissolution tests using a 3-L sample of Tank 51 sludge slurry (funded by DOE EM-21). ${ }^{1}$ The aluminum dissolved sludge resulting from this testing was then used to determine potential downstream impacts so technical issues could be identified before the start of SB5 processing. The potential downstream impacts assessed include the Tank Farm sludge washing and concentration process and the DWPF Chemical Process Cell (CPC) and melter processing envelopes.

This report documents:

- The washing (addition of water to dilute the sludge supernate) and concentration (decanting of supernate) of the Post Aluminum Dissolution sample to adjust sodium content and weight percent insoluble solids to Tank Farm projections of Tank 51 after aluminum dissolution.

- The performance of a DWPF Chemical Process Cell (CPC) simulation using the washed Post Aluminum Dissolution sample. This includes a Sludge Receipt and Adjustment (SRAT) cycle where acid is added to the sludge to destroy nitrite and remove mercury, and a Slurry Mix Evaporator (SME) cycle where glass frit is added to the sludge in preparation for vitrification. Processing parameters for the processing were based on work with a non radioactive simulant, also presented in this report.

- A comparison of CPC processing between Tank 51 with and without aluminum dissolution.

This work is controlled by a Task Technical and Quality Assurance Plan (TTQAP) ${ }^{2}$, and analyses are guided by an Analytical Study Plan ${ }^{3}$. This work is Technical Baseline Research and Development (R\&D) for the Department of Energy (DOE) Office of Cleanup Technologies (EM-21). 


\subsection{APPROACH}

The general experimental methods for this task are presented in this section. First, a broad overview of the analytical techniques is given. Second, a description of the washing process is presented, along with actual washing amounts. Third, a boiling test to evaluate the impact of potentially high aluminum in a SRAT receipt sample is described. Fourth, preparation of the simulant SRAT sample is presented. Fifth, laboratory scale CPC processing is outlined. Finally, the methodology for rheological measurements is given.

\subsection{General Description of Analytical Methods}

Analyses for this task used guidance of an Analytical Study Plan (ASP) ${ }^{3}$. Sample request forms were used for samples to be analyzed, and analyses followed the guidelines and means of sample control stated in the ASP for the task. A unique laboratory identification management system (LIMS) number was assigned to each sample for tracking purposes. Analyses were performed using approved analytical and Quality Assurance (QA) procedures.

Procedures for analysis of the simulant material can be found in Reference 4. For the radioactive materials, procedures and work instructions for density, percent solids, and supernate and slurry dilutions are also given in Reverence 4. Procedures for digestions and sample analyses are given in Reference 5.

Radioactive slurry total base was determined by a direct in-Cell titration of slurry and a titration by SRNL Analytical Development (SRNL-AD) using diluted slurry.

\subsection{Washing of Post Aluminum Dissolution Tank 51 Sample and Preparation of the SC-4 SRAT Receipt Sample}

Sludge slurry remaining from the aluminum dissolution process ${ }^{1}$ was to be washed following Tank Farm planned washes: three washes/decants. ${ }^{6}$ Because the Tank 7 addition was not simulated in the SRNL washes, wash addition amounts were based on sodium concentration rather than a combination of sodium and other anions. However, measured sodium was lower than predicted following each of the SRNL washes, and only two were required in the SRNL Shielded Cells demonstration. Washing results are discussed in Section 3.1. The general outline of a wash cycle was:

- $\quad$ Add deionized water

- Mix for 30 minutes

- Allow solids to settle and supernate to clarify

- Decant the supernate once the target amount is obtained

Washing was performed in a 4-L wide mouth glass bottle. The bottle had a centimeter scale taped to the side. This scale enabled estimation of the slurry and supernate volumes. Actual sludge and supernate amounts were determined by mass, and volumes were calculated from mass and density measurements. Washing strategy was based on Tank Farm planned washes as given in Reference 6 (after a Tank 7 to 51 transfer and a decant). Because the Tank 7 addition was not simulated in the SRNL washes, wash addition amounts were based on sodium concentration rather than a combination of sodium and other anions. Decant amounts were targeted based on weight percent insoluble solids. Also, since the nitrite to nitrate ratio in the post aluminum dissolution sludge was approximately two, well above the Tank Farm corrosion requirement of 1.66, and since the sludge had large quantities of hydroxide from the caustic addition during aluminum dissolution, deionized water was used for washing rather than inhibited water. 
Wash water target amounts were determined by calculating the supernate volume in the sludge to be washed and then using a rearranged version of the dilution equation $V_{1} \cdot C_{1}=V_{2} \cdot C_{2}$ with $V_{2}=V_{1}+V_{w}$. Note that the accuracy of this equation is dependant on the applicability of the assumptions that volume is conserved and there is no precipitation or dissolving of solids during washing. This is the same methodology used in Tank Farm planning spreadsheets.

$V_{w}=V_{1} \cdot\left(\frac{C_{1}-C_{2}}{C_{2}}\right)$

where,

$V_{w}=$ volume of wash water to be added

$V_{1}=$ volume of supernate

$C_{1}=$ sodium concentration in supernate

$C_{2}=$ target sodium concentration

Decant amounts were targeted based on an insoluble solids balance, assuming that the insoluble solids mass remained constant during the washing process. Sludge solids level was periodically recorded during settling between wash water additions. These recordings are presented in Appendix A and discussed in Section 3.2. However, actual decant amounts during each wash were limited by the settled sludge level, and the ability to remove supernate without disturbing the sludge solids. It should be noted that the interface between the sludge solids and supernate was very clear. Following Washes 1 and 2, a peristaltic pump was used to remove supernate. But, following the decant after Wash 2 (designated as Decant 2a), insoluble solids content was unacceptably low. More supernate was removed (Decant 2b) using a large slurry pipette after an additional 14 days of settling. Use of the pipette allowed decanting closer to the sludge solids without interfering with the solids layer, compared to the relatively higher suction of the pump. It should be noted that sludge level remained unchanged during these additional days of settling. Table 2-1 details actual wash and decant amounts along with targets and analytical results needed for subsequent washes. As stated above, only two washes were performed at SRNL rather than the Tank Farm planned three due to the lower than predicted sodium concentration following the SRNL second wash.

Sludge level was periodically recorded during settling between wash water additions. These recordings are presented in Appendix A and discussed in Section 3.2.

The sludge slurry remaining after Decant 2b was characterized for use in the SC-4 SRAT and SME cycles and will be subsequently referred to as the SRAT receipt. 
WSRC-STI-2008-00086

Revision 0

Table 2-1. SRNL Washing Amounts

\begin{tabular}{|c|c|c|c|c|c|c|c|c|c|c|c|}
\hline & $\begin{array}{c}\text { Post Al } \\
\text { Diss Tk51 }\end{array}$ & $\begin{array}{c}\text { Wash } \\
1^{\mathrm{a}} \\
\end{array}$ & $\begin{array}{c}\text { Decant } \\
1\end{array}$ & $\begin{array}{c}\text { After } \\
\text { Decant } 1^{\mathrm{b}} \\
\end{array}$ & 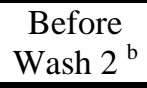 & $\begin{array}{c}\text { Wash } \\
2^{\mathrm{a}}\end{array}$ & $\begin{array}{c}\text { Decant } \\
2 \mathrm{a}\end{array}$ & $\begin{array}{c}\text { After } \\
\text { Decant } 2 \mathrm{a}^{\mathrm{b}}\end{array}$ & $\begin{array}{c}\text { Before } \\
\text { Decant 2b }\end{array}$ & $\begin{array}{c}\text { Decant } \\
\text { 2b }\end{array}$ & $\begin{array}{c}\text { After } \\
\text { Decant 2b }\end{array}$ \\
\hline $\begin{array}{l}\text { Sludge Slurry Mass } \\
\text { (g) }\end{array}$ & 1,706 & & & 2,013 & 1,881 & & & 1,595 & 1,468 & & 1,064 \\
\hline $\begin{array}{l}\text { Wash Water or } \\
\text { Decant (g) }\end{array}$ & & 1,118 & $(808)$ & & & 884 & (1170) & & & $(404)$ & \\
\hline $\begin{array}{l}\text { Wt\% Insoluble } \\
\text { Solids }\end{array}$ & 6.44 & & & 6.52 & 6.52 & & & 8.87 & 8.87 & & 12.0 \\
\hline Supernate Mass (g) $^{*}$ & 1,596 & & & 1,882 & 1,758 & & & 1,454 & 1,338 & & 936 \\
\hline $\begin{array}{l}\text { Supernate Density } \\
\text { (g/mL) }\end{array}$ & 1.21 & & & 1.12 & 1.12 & & & 1.07 & 1.07 & & 1.07 \\
\hline $\begin{array}{l}\text { Supernate Volume } \\
(\mathrm{mL})^{\dagger}\end{array}$ & 1,319 & & & 1,680 & 1,570 & & & 1,358 & 1,250 & & 875 \\
\hline $\begin{array}{l}\text { Target/Predicted } \mathrm{Na} \\
(\mathrm{M})\end{array}$ & & & 2.65 & 2.65 & & & 1.60 & 1.60 & & & \\
\hline Measured Na (M) & 4.86 & & 2.42 & 2.42 & 2.42 & & 1.42 & 1.42 & 1.42 & 1.42 & 1.42 \\
\hline
\end{tabular}

${ }^{a}$ Wash volume targets were calculated using Equation 2-1. Given in this table are actual wash water amounts added to the sludge slurry.

${ }^{\mathrm{b}}$ After each decant, a sample of the sludge slurry was taken. Therefore, the after decant and before wash values are not equal.

* Supernate mass $=$ Sludge Slurry mass $\cdot\left(1-\frac{w t \% \text { insol }}{100}\right)$

$\dagger$ Supernate vol $=\frac{\text { Supernate mass }}{\text { Supernate density }}$ 


\subsection{Post Aluminum Dissolution Boiling Evaluation}

Because of pump water in-leakage in Tank 40, DWPF is removing water from the SRAT receipt material by boiling to increase total solids prior to the start of the SRAT cycle. To determine whether "boiling" of post-aluminum dissolution Tank 51 sludge produces unusual changes in sludge consistency due to the relatively high aluminum content in the supernate, a sludge sample was evaluated.

Approximately $75 \mathrm{~mL}$ of washed post-aluminum dissolution sludge ${ }^{*}$ was combined with $\sim 15 \mathrm{~mL}$ distilled water (used for rinsing purposes) in a glass boiling vessel (see Figure 2-1 for a photo of the apparatus). While stirring, the mixture was boiled for eight hours. During this period, a total of $\sim 45 \mathrm{~mL}$ of condensate was collected. Considering the contribution of the rinse water $(15 \mathrm{~mL})$, the volume of condensate derived from the sludge slurry was $\sim 30 \mathrm{~mL}$. Visual observations regarding the consistency of the sludge slurry were made during the boiling period and after completion of the boiling period. Total solids content of the final concentrated sludge (after boiling and cooling) was determined through replicate measurements.

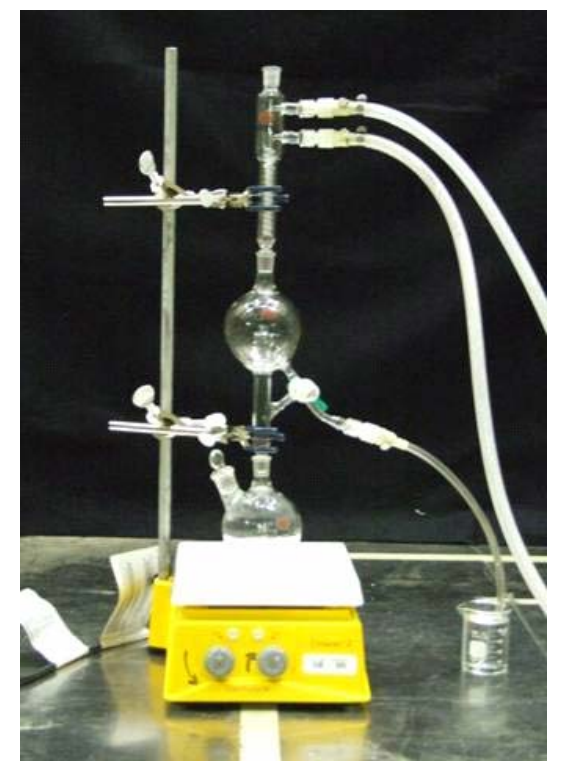

Figure 2-1. Apparatus for Sludge Boiling Evaluation

\subsection{Simulant SRAT Receipt Preparation}

A Tank 51 simulant was prepared by precipitating $\mathrm{MnO}_{2}$, combining the $\mathrm{MnO}_{2}$ with a metal nitrate solution, coprecipitation of the metals as hydroxides, addition of sodium carbonate, washing the supernate to lower the nitrate concentration below the final target, decanting excess supernate and adding soluble chemicals to reach the desired target. The sludge simulant can match the chemical composition target but does not necessarily contain the same aluminum species as are present in the waste tank. The simulant's aluminum is likely all present as the gibbsite form, an easily dissolved form of aluminum, with little or no boehmite, as the simulant does not have the same time and temperature history as the actual waste. To simulate the dissolution of aluminum, the sludge simulant was contacted with $50 \mathrm{wt} \%$ sodium hydroxide to dissolve insoluble aluminum then was washed/decanted with DI water to lower the sodium

\footnotetext{
${ }^{*}$ Wash 2 following Decant 2a slurry, with a total solids content of $16.3 \mathrm{wt} \%$ and a density of $1.14 \mathrm{~g} / \mathrm{mL}$
} 
concentration to $1.36 \mathrm{M}$. No attempt was made to achieve a dissolved aluminum target. The sludge was thought to be conservative in that all the $\mathrm{Al}$ was dissolved and more aluminum was removed from the simulant (80\%) than actual waste (35\%).

\subsection{Chemical Process Cell (CPC) Processing (SRAT Cycle, SME Cycle)}

The SRAT and SME cycles were conducted following procedures in the Process Science and Engineering Section procedure manual. ${ }^{4}$ A summary of each cycle is presented in Table 2-2 below.

Table 2-2. Summary of CPC Processing

\begin{tabular}{|c|c|}
\hline SRAT Cycle & SME Cycle \\
\hline $\begin{array}{ll}\text { - } & \text { Acid Calculation } \\
\text { - } & \text { Heating of SRAT Receipt to } 93 \\
& { }^{\circ} \mathrm{C} \\
\text { - } & \text { Addition of nitric and formic } \\
\text { - } & \text { acids per acid calculation } \\
\text { - } & \text { Heat to boiling } \\
\text { - } & \text { a target wt } \% \text { total solids } \\
\text { - } & \text { Reflux for } 24 \text { hours }\end{array}$ & $\begin{array}{l}\text { - Addition and removal of water to } \\
\text { simulate addition and removal of } \\
\text { water from the decontamination } \\
\text { of } 5 \text { glass canisters } \\
\text { - Addition of frit and dilute formic } \\
\text { acid } \\
\text { - Concentration (water removal) to } \\
\text { target } 45-50 \mathrm{wt} \% \text { total solids. }\end{array}$ \\
\hline
\end{tabular}

Simulant and real-waste processing runs were performed using a vessel designed to process one liter of sludge. For the in-Cell run, the SRAT rig was assembled and tested in the SRNL Shielded Cells Mockup area and placed into the Shielded Cells fully assembled. A detailed description of the SRAT rig and testing of the rigs can be found in References 7 and 8 . The intent of the equipment is to functionally replicate the DWPF processing vessels. The glass kettle is used to replicate both the SRAT and the SME, and it is connected to the SRAT Condenser and the Mercury Water Wash Tank (MWWT). Because the DWPF Formic Acid Vent Condenser (FAVC) does not directly impact SRAT and SME chemistry, it is not included in SRNL Shielded Cells CPC processing. Instead, a simple "cold finger" condenser is used to cool offgas to approximately $20{ }^{\circ} \mathrm{C}$ below ambient to remove excess water before the gas reaches the gas chromatograph for characterization. The Slurry Mix Evaporator Condensate Tank (SMECT) is represented by a sampling bottle that is used to remove condensate through the MWWT. For the purposes of this paper, the condensers and wash tank are referred to as the offgas components. A sketch of the experimental setup is given as Figure 2-2. 


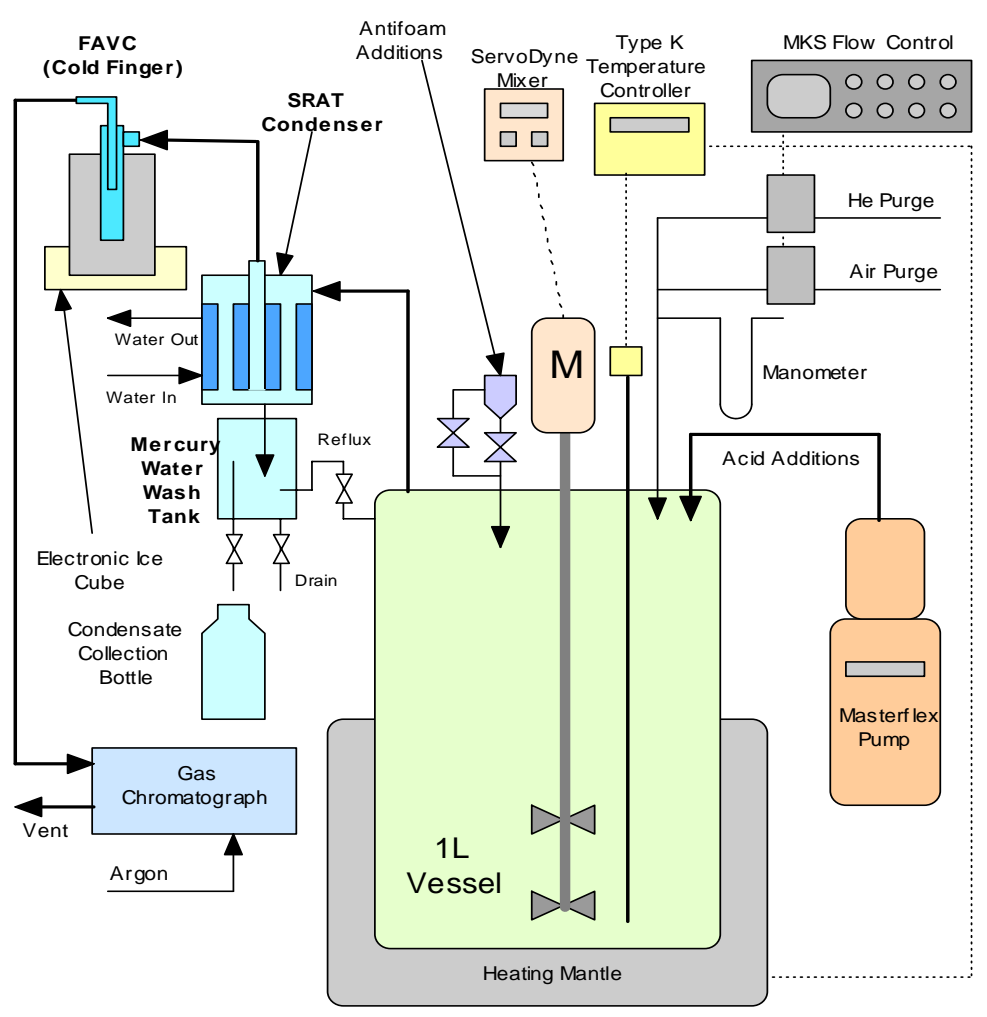

Figure 2-2. Schematic of SRAT Equipment Set-Up

SRAT and SME processing parameters are given in References 9 and 10. Offgas hydrogen, oxygen, nitrogen, nitrous oxide, and carbon dioxide concentrations were measured during the experiments using in-line instrumentation. Helium was introduced at a concentration of $0.5 \%$ of the total air purge as an inert tracer gas so that total amounts of generated gas and peak generation rates could be calculated. During the runs, the kettle was monitored to observe reactions that were occurring to include foaming, air entrainment, rheology changes, loss of heat transfer capabilities, and offgas carryover. Observations were recorded in laboratory notebooks ${ }^{9,10}$ and are discussed in Section 3.0.

Concentrated nitric acid (50-wt\%) and formic acid (90-wt\%) were used to acidify the sludge and perform neutralization and reduction reactions during processing. The amounts of acid to add for each run were determined using the existing DWPF acid addition equation ${ }^{11}$. The split of the acid was determined using the REDOX equation currently being used in DWPF processing ${ }^{12}$. To account for the reactions and anion destructions that occur during processing, assumptions about nitrite destruction, nitrite to nitrate conversion, and formate destruction were made for each run. The values used for each run are provided in Section 3.0.

SRAT processing included the dewater time in boiling plus an additional time of reflux to simulate DWPF processing conditions. SME processing included the addition and removal (by boiling) of water to simulate DWPF's addition and removal of water used for decontaminating canisters of glass. The frit addition was split into two equal portions. The frit was added with water and formic acid at DWPF prototypical conditions. Concentration was performed after each frit addition and then heat was removed to allow for the next frit addition. A final concentration was performed at the end of the run to meet the target total solids. The SRAT condenser was maintained at $25{ }^{\circ} \mathrm{C}$ during the run, while the cold finger condenser remained below $5{ }^{\circ} \mathrm{C}$. 


\subsection{Rheology}

Rheological properties were determined using a Haake M5/RV30 rotoviscometer. The M5/RV30 is a Searle sensor system, where the bob rotates and the cup is fixed. The torque and rotational speed of the bob are measured. Heating/cooling of the cup/sample/bob is through the holder that holds the cup. The shear stress is determined from the torque measurement and is independent of the rheological properties. Conditions that impact the measured torque are; slip (material does not properly adhere to the rotor or cup), phase separation (buildup of liquid layer on rotor), sedimentation (particles settling out of the shearing zone), homogeneous sample (void of air), lack of sample (gap not filled), excess sample (primarily impacts rheologically thin fluids), completely filling up the void below the bob (air buffer that is now filled with fluid) and Taylor vortices. The first five items yield lower stresses and the last three add additional stresses. The shear rate is geometrically determined using the equations of change (continuity \& motion) and is that for a Newtonian fluid. This assumption also assumes that the flow field is fully developed and the flow is laminar. The shear rate can be calculated for non-Newtonian fluid using the measured data and fitting this data to the rheological model or corrected as recommended by Darby ${ }^{13}$. In either case, for shear thinning non-Newtonian fluids typical of Savannah River Site (SRS) sludge wastes, the corrected shear rates are greater than their corresponding Newtonian shear rates, resulting in a thinner fluid. Correcting the flow curves will not be performed in this task, resulting in a slightly more viscous fluid.

The bob typically used for measuring tank sludge or SRAT product is the MV I rotor. For SME product, the MV II rotor is used to perform the measurements, due to the larger frit particles that are present in the SME product. The MV II has a larger gap to accommodate the larger frit particles. The shape, dimensions, and geometric constants for the MV I and MV II rotors are provided in Table 2-3.

Prior to performing the measurements, the rotors and cups are inspected for physical damage. The torque/speed sensors and temperature bath are verified for functional operability using a bob/cup combination with a National Institute of Standards and Technology (NIST) traceable Newtonian oil standard, using the MV I rotor. The resulting flow curves are then fitted as a Newtonian fluid and this calculated viscosity must be within $\pm 10 \%$ of the reported NIST viscosity at a given temperature for the system to be considered functionally operable. A N10 oil standard was used to verify system operability prior to the sludge measurements.

The flow curves for the sludge are fitted to the down curves using the Bingham Plastic rheological model, Equation 2-2, where $\tau$ is the measured stress $(\mathrm{Pa}), \tau_{\mathrm{o}}$ is the Bingham Plastic yield stress $(\mathrm{Pa}), \mu_{\infty}$ is the plastic viscosity $(\mathrm{Pa} \cdot \mathrm{sec})$, and $\dot{\gamma}$ is the measured shear rate $\left(\mathrm{sec}^{-1}\right)$. During all these measurements, typically the sample remained in the cup for the $2^{\text {nd }}$ measurement, due to the sample availability. If thixotropic properties or unique flow behavior were obvious on the first sample, efforts were made to perform additional measurements by reloading the sample.

$$
\tau=\tau_{o}+\mu_{\infty} \dot{\gamma}
$$


WSRC-STI-2008-00086

Revision 0

Table 2-3. MV I and MV II Rotor Specifications and Flow Curve Program

\begin{tabular}{|c|c|c|c|}
\hline Rotor Design & \multicolumn{3}{|c|}{ Dimensions and Flow Curve Program } \\
\hline & Rotor Type & MV I & MV II \\
\hline & Rotor radius $-\mathrm{R}_{\mathrm{i}}(\mathrm{mm})$ & 20.04 & 18.40 \\
\hline & Cup Radius - $\mathrm{R}_{\mathrm{a}}(\mathrm{mm})$ & 21.0 & 21.0 \\
\hline & Height of rotor -L (mm) & 60 & 60 \\
\hline & $\begin{array}{c}\text { Sample Volume }\left(\mathrm{cm}^{3}\right) \\
\text { minimum }\end{array}$ & 40 & 55 \\
\hline & A factor (Pa/\%torque) & 3.22 & 3.76 \\
\hline & $\mathrm{M}$ factor $\left(\mathrm{s}^{-1} / \% \mathrm{RPM}\right)$ & 11.7 & 4.51 \\
\hline & Shear rate range $\left(\mathrm{s}^{-1}\right)$ & $0-600$ & $0-300$ \\
\hline & Ramp up time (min) & 5 & 5 \\
\hline & Hold time (min) & 1 & 1 \\
\hline & Ramp down time (min) & 5 & 5 \\
\hline
\end{tabular}




\subsection{RESULTS AND DISCUSSION}

\subsection{Washing and SRAT Receipt Preparation}

Presented in Table 3-1 are the percent solids and density measurements of the Tank 51 Post Aluminum Dissolution sample throughout washing.

Table 3-1. Weight Percent Solids and Density During Tank 51 Post Aluminum Dissolution Washing

\begin{tabular}{|l|c|c|c|c|}
\hline Physical Property & Post Al Diss. & Wash/Decant 1 & Wash/Decant 2a $^{*}$ & Decant 2b $^{*}$ \\
\hline Wt \% Total Solids (Slurry Basis) & 28.0 & 18.5 & 16.3 & 19.1 \\
\hline Wt \% Insoluble solids (Slurry Basis) & 6.44 & 6.52 & 8.87 & 12.0 \\
\hline Wt \% Soluble Solids (Slurry Basis) & 21.5 & 11.9 & 7.41 & 7.16 \\
\hline Slurry Density (g/mL) & 1.27 & 1.19 & 1.14 & 1.20 \\
\hline Supernate Density (g/mL) & 1.21 & 1.12 & 1.07 & 1.07 \\
\hline
\end{tabular}

${ }^{*}$ For Wash 2, there were two decants (a and b). A second decant, using a pipette instead of a relatively high suction peristaltic pump, was necessary to increase total and insoluble solids content.

Given in Table 3-2 are the aluminum, sodium, nitrite, and nitrate content of supernates during washing. From this data it appears that soluble aluminum is being removed from the sludge along with the soluble species. To confirm that the decrease is caused by washing and not precipitation, the ratio of total aluminum to iron (essentially insoluble and inert in washing) in the sludge can be used. A decrease in this ratio indicates aluminum removal. Sodium removed during washing can also be calculated using this methodology. Table 3-3 shows results of this calculation. Calculations and the ratios are given in Appendix B.

Table 3-2. Major Components of the Supernate During Washing of the Post Aluminum dissolution Sample

\begin{tabular}{|l|c|c|c|}
\hline & Post Al Dissolution & Wash 1 Supernate & Wash 2 Supernate $^{b}$ \\
\hline $\mathrm{Al}(\mathrm{M})$ & 0.355 & 0.170 & 0.095 \\
\hline $\mathrm{Na}(\mathrm{M})^{\mathrm{a}}$ & 4.86 & 2.42 & 1.42 \\
\hline $\mathrm{NO}_{2}{ }^{-}(\mathrm{M})$ & 0.415 & 0.187 & 0.107 \\
\hline $\mathrm{NO}_{3}{ }^{-}(\mathrm{M})$ & 0.218 & 0.0871 & 0.0510 \\
\hline
\end{tabular}

${ }^{\text {a }}$ Sodium was also measured by ICP-AES: 5.26 M Post Diss., $2.55 \mathrm{M}$ Wash 1, and 1.43 M Wash 2. During the washing process, AA was used since it was available sooner, and AA is generally a better method for determining $\mathrm{Na}$.

${ }^{\mathrm{b}}$ It should be noted that there were two decants after Wash 2 - Decant 2a and Decant 2b, having the same composition. 
Table 3-3. Percentages of Aluminum and Sodium Removed by Dissolution and Washing

\begin{tabular}{|c|c|}
\hline $\begin{array}{c}\text { \% Al Removed by Dissolution (relative to Al } \\
\text { in as-received Tank 51 sample) }\end{array}$ & 21 \\
\hline $\begin{array}{c}\text { \% Al Removed by Washing (relative to Al in } \\
\text { as-received Tank 51 sample) }\end{array}$ & 14 \\
\hline $\begin{array}{c}\text { Total \% Al Removed (relative to Al in as- } \\
\text { received Tank 51 sample) }\end{array}$ & 35 \\
\hline $\begin{array}{c}\text { \% Na Removed by Washing (relative to post } \\
\text { Al dissolution sample) }\end{array}$ & 66 \\
\hline $\begin{array}{c}\text { \% Increase in Na (relative to Na in as-received } \\
\text { Tank 51 sample) }\end{array}$ & 14 \\
\hline
\end{tabular}

The table above does show that aluminum was removed during washing. However, a comparison of predicted (by mass balances) to measured insoluble solids indicates some precipitation, most likely a sodium-aluminum compound Therefore, the weight percents of $\mathrm{Al}$ and $\mathrm{Na}$ were calculated prior to and after washing using Equation 3-1. This equation converts the supernate (soluble) and total solids (total) concentrations of element i to a slurry basis.

$W t \%_{\text {sol }}=\frac{C_{i} \cdot M W_{i} \cdot\left(100-W t \%_{I S}\right)}{\rho_{\text {sup }} \cdot W_{i} \cdot W t \%_{T S}} \cdot 10$

where,

$W t \%_{\text {sol }}=$ weight $\%$ of element $i$ that is soluble (mass soluble/total mass $\mathrm{x} 100$ )

$C_{i}=$ concentration of element $i$ in the supernate (mol/L supernate)

$M W_{i}=$ molecular weight of element $i$

$\rho_{\text {sup }}=$ supernate density $(\mathrm{g} / \mathrm{mL})$

$W_{i}=$ weight percent of element $i$ in the total solids.

$W \%_{I S}=$ weight fraction insoluble solids in the slurry (1- $W_{I S}$ is the weight fraction supernate)

$W \%_{T S}=$ weight percent total solids

Percent soluble aluminum and sodium are presented in Table $3-4^{\dagger}$. As can be seen, a significant amount of sodium precipitated during washing. Unfortunately, analysis of the sludge solids to determine the precipitated species (e.g., x-ray diffraction or scanning electron microscopy) is not practical due to the high dose rate of the solids. One implication of insoluble sodium is that a washing target based on soluble sodium may underestimate the sodium content in the next sludge batch.

Table 3-4. Calculated Weight Percent Soluble Aluminum and Sodium

\begin{tabular}{|l|c|c|c|}
\hline & $\begin{array}{c}\text { As-Received } \\
\text { Tank 51 }\end{array}$ & $\begin{array}{c}\text { Post Al } \\
\text { Dissolution }\end{array}$ & $\begin{array}{c}\text { After } \\
\text { Washing }\end{array}$ \\
\hline $\mathrm{Al}$ (\% soluble) & 1 & 30 & 8 \\
\hline $\mathrm{Na}$ (\% soluble) & 92 & 87 & 62 \\
\hline
\end{tabular}

A comparison of the elemental analysis of the total solids before and after aluminum dissolution and washing is presented in Table 3-5. As expected the primarily insoluble species (e.g., Fe, Mg) increase in

${ }^{\dagger}$ Data used to calculate the percent soluble in Table 3-4 can found in Table 3-1, Table 3-2, Table 3-5, and Appendix B. 
concentration as primarily soluble species such as nitrate and nitrite are removed by washing. The effect of washing on the partially soluble $\mathrm{Al}$ is not obvious on a total solids basis. At first glance, it might appear that $\mathrm{Al}$ was not significantly removed during $\mathrm{Al}$ dissolution/washing since its concentration in the total solids dropped only slightly. But, a comparison of Fe (predominantly insoluble) to Al ratios does show that $\mathrm{Al}$ was removed during dissolution and washing: $\mathrm{Al} / \mathrm{Fe}=2.15$ in the as-received Tank 51 sample, 1.7 before washing, and 1.4 after washing - see discussion on aluminum removal above.

\section{Table 3-5. Comparison of Major Elements (>0.1\%) in the Total Solids in the As-Received Tank 51} Sample and the Post Aluminum Dissolution/Washed (SRAT Receipt) Sample

\begin{tabular}{|l|c|c|}
\hline & $\begin{array}{c}\text { As-Received } \\
\text { Tank 51 }\end{array}$ & $\begin{array}{c}\text { After Wash 2/ } \\
\text { Decant 2b }\end{array}$ \\
\hline & \multicolumn{2}{|c|}{ Wt\% of Total Solids $^{\text {. }}$} \\
\hline $\mathrm{Al}$ & 15.6 & 13.9 \\
\hline $\mathrm{Ca}$ & 0.81 & 1.12 \\
\hline $\mathrm{Fe}$ & 7.27 & 9.97 \\
\hline $\mathrm{Hg}$ & 1.73 & 2.84 \\
\hline $\mathrm{Mg}$ & 0.30 & 0.42 \\
\hline $\mathrm{Mn}$ & 1.73 & 2.44 \\
\hline $\mathrm{Na}$ & 14.5 & 22.6 \\
\hline $\mathrm{Ni}$ & 0.65 & 0.86 \\
\hline $\mathrm{Si}$ & 0.44 & 0.60 \\
\hline $\mathrm{U}$ & 1.63 & 2.41 \\
\hline
\end{tabular}

${ }^{\mathrm{a}}$ Data from Reference 1.

A better elemental basis for DWPF use, and ultimately glass fabrication, is weight percent of calcined solids (elementals based on solids heated to $1100{ }^{\circ} \mathrm{C}$ for two hours). This basis is essentially an oxide basis. The total solids measurement includes nitrates, nitrites, and other cations, while the calcined solids contain primarily cations and oxygen (oxides), the actual components of the waste that are vitrified. Weight percent of calcined solids basis is calculated as follows:

$w t \%$ of element $\mathrm{i}$ in calcined solids $=w t \%$ of element $\mathrm{i}$ in total solids $\times \frac{w t \% \text { total solids }}{w t \% \text { calcine solids }}$

Presented in Table 3-6 are the elemental compositions on a wt\% calcined solids basis of the as-received Tank 51 sample and the post aluminum dissolution sample after washing (the SRAT receipt sample). The as-received Tank 51 sample is very similar to the Sludge Batch 4 qualification sample, ${ }^{14}$ and the washed sample composition should be similar to Sludge Batch 5 with less Purex sludge contribution. This comparison shows that the aluminum dissolution process will indeed lower the aluminum contribution from the waste to the DWPF glass, but sodium content may increase due to difficulties in washing to obtain the target endpoint. 
WSRC-STI-2008-00086

Revision 0

Table 3-6. Comparison of Major Elements in the As-Received Tank 51 Sample and the Post Aluminum Dissolution/Washed (SRAT Receipt) Sample on a Calcined Solids Basis

\begin{tabular}{|l|c|c|}
\hline & $\begin{array}{c}\text { As Received } \\
\text { Tank 51 }^{\mathbf{a}}\end{array}$ & $\begin{array}{c}\text { After Wash 2/ } \\
\text { Decant 2b }\end{array}$ \\
\hline & \multicolumn{2}{|c|}{ Wt\% of Calcined Solids $^{\text {bt }}$} \\
\hline $\mathrm{Al}$ & 22.7 & 16.0 \\
\hline $\mathrm{Ca}$ & 1.18 & 1.29 \\
\hline $\mathrm{Fe}$ & 10.6 & 11.5 \\
\hline $\mathrm{Mg}$ & 0.43 & 0.48 \\
\hline $\mathrm{Mn}$ & 2.52 & 2.81 \\
\hline $\mathrm{Na}$ & 21.1 & 26.0 \\
\hline $\mathrm{Ni}$ & 0.94 & 0.99 \\
\hline $\mathrm{Si}$ & 0.63 & 0.69 \\
\hline $\mathrm{U}$ & 2.37 & 2.77 \\
\hline${ }^{\mathrm{a}} \mathrm{wt} \%$ total solids $=15.5, \mathrm{wt} \%$ calcined solids $=10.7$ \\
${ }^{\mathrm{b}} \mathrm{wt} \%$ total solids $=19.1, \mathrm{wt} \%$ calcined solids $=16.6$
\end{tabular}

\subsection{Sludge Settling}

Sludge level was recorded during dissolution and washing. The results are presented graphically in Figure $3-1 .^{\ddagger}$ Because starting sludge heights were different during dissolution and the two washes, sludge height is given in terms of height relative to the start of settling. As can be seen in the figure, there is no trend in settling behavior during washing; settling during the first wash was slower than during dissolution, but Wash 2 settling was faster. In all cases, sludge level dropped to $60 \%$ of the original height after approximately one week, and then nearly leveled off. Note that the settling behavior for Wash 2 was recorded only until the first Wash 2 decant (Decant 2a); sludge level remained essentially unchanged after the first decant. ${ }^{\S}$

\footnotetext{
‡ Settling data during aluminum dissolution was published previously in Reference 1 .

${ }^{\S}$ As discussed in Section 2.2, Decant $2 \mathrm{~b}$ was accomplished with a slurry pipette, enabling a decant very close to the sludge level.
} 


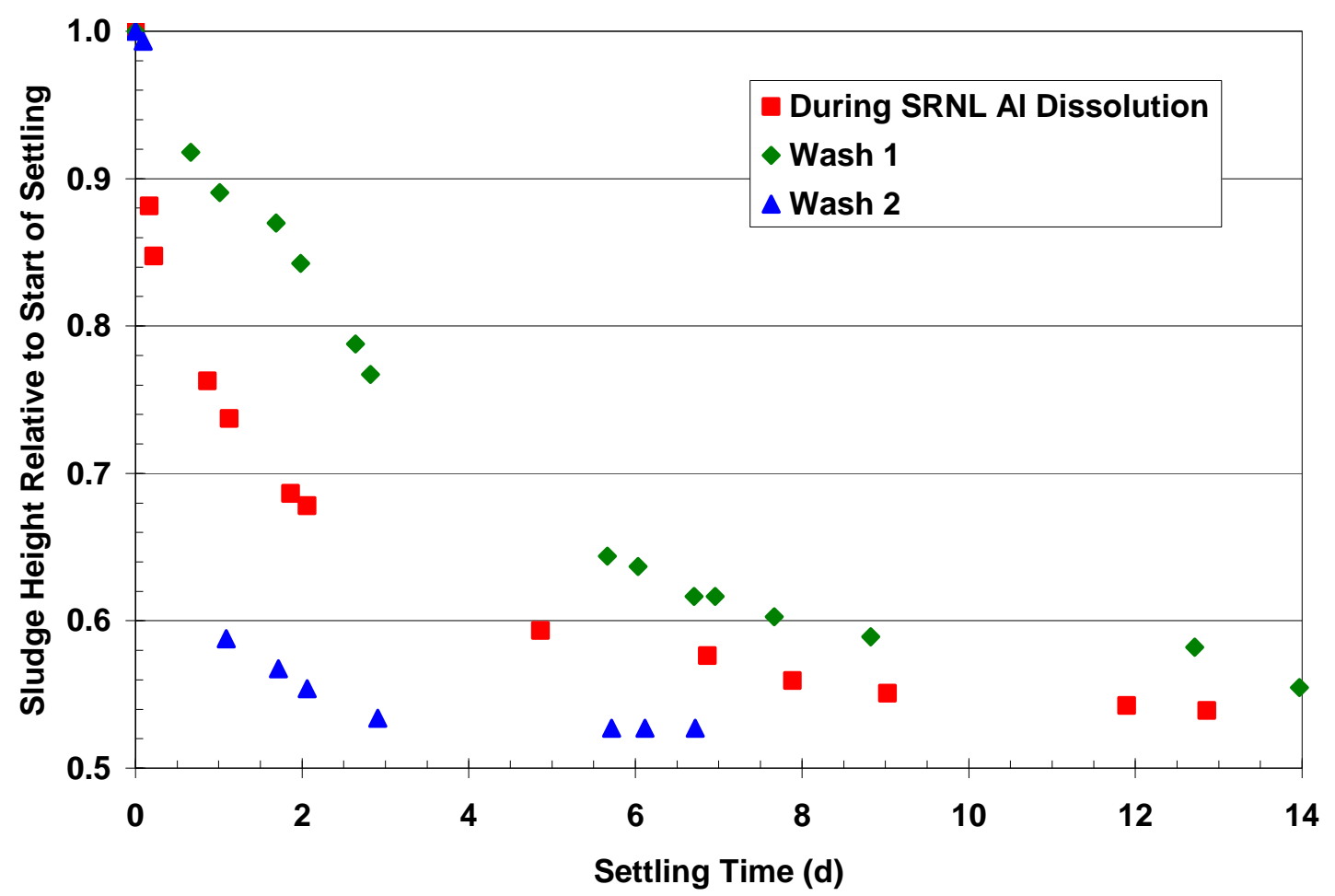

Figure 3-1. Sludge Settling During Aluminum Dissolution and Washing

\subsection{Results of Boiling the Wash 2/Decant 2a Slurry}

No unusual changes in sludge consistency were observed during or after the boiling of a sample of sludge after Wash 2/Decant 2a. Although the final concentrated sludge was very thick, it remained fluid, not gelatinous. The total solids content of the final sludge was $33.4 \%$, which was about twice that of the initial material (16.3 wt \%, prior to rinse water addition and boiling).

Based on the solids content and density of the initial material, approximately $40 \%$ of the slurry's original water was removed during this demonstration. These conditions bound what is targeted in normal DWPF operations. Therefore, boiling of post-dissolution Tank 51 sludge is not expected to produce unusual changes in sludge consistency.

\subsection{SRAT Receipt Characterization and Acid Addition Calculations}

The DWPF SRAT process relies upon use of the acid calculation to estimate the required acid necessary to complete reactions. This calculation uses measured analytical inputs. Errors in these measurements can result in too little acid being added resulting in incomplete reactions or too much acid being added resulting in excess formic acid causing high hydrogen generation rates. Therefore, the washed post aluminum dissolution Tank Farm Tank 51 sample was extensively characterized to determine the inputs. The results of the SC-4 SRAT receipt characterization are provided in Table 3-7, along with the SC-3 (washed Tank 51 sample without Al dissolution) ${ }^{15}$ and the simulant used to recommend the acid 
stoichiometry for the SC-4 run. Table 3-8 gives the additional acid calculation inputs (e.g., formate destruction).

For the SC-4 total base measurement, two methods were used to measure total base: 1) a titration of slurry diluted by a factor of $\sim 30$ was performed by SRNL-AD (this method used an autotitrator and yielded a result of 1.5 mol base per liter of slurry), and 2) a direct titration of slurry was performed in the Shielded Cells by SRNL-PS\&E (this titration was performed manually and yielded a result of $2.1 \mathrm{~mol}$ base per liter of slurry). This second method is the nominal method used in the Shielded Cells DWPF demonstrations.

Table 3-7. Characterization Results and Acid Calculation Inputs of the Post Aluminum Dissolution Tank 51 (SC-4 SRAT Receipt) Sample and the Corresponding Non Rad Simulant SRAT Receipt (SB5-4 \& -5) With Comparison to a Pre Aluminum Dissolution SRAT Receipt (SC-3) Sample

\begin{tabular}{|c|c|c|c|c|}
\hline Measurement & Units & SC- $3^{a}$ & $\begin{array}{c}\text { SB5- } \\
\text { 4/SB5-5 }\end{array}$ & SC-4 \\
\hline Total Solids, & wt\% of slurry & 19.5 & 13.00 & 19.1 \\
\hline Insoluble Solids, wt\% of slurry & wt\% of slurry & 12.5 & 5.98 & 12.0 \\
\hline Soluble Solids, wt\% of slurry & wt\% of slurry & 7.0 & 7.02 & 7.16 \\
\hline Calcined Solids, wt\% of slurry & wt $\%$ of slurry & 14.3 & 10.02 & 16.6 \\
\hline Slurry Density, kg/L & kg/L slurry & 1.14 & 1.11 & 1.20 \\
\hline Supernate Density, kg/L & kg/L supernate & 1.06 & NA & 1.07 \\
\hline $\mathrm{Na}, \mathrm{wt} \%$ of total solids & wt\% of total solids & 11.8 & NA & 22.6 \\
\hline Hg, wt\% of total solids & wt\% of total solids & 2.57 & 5.55 & 2.84 \\
\hline Mn, wt\% of total solids & wt\% of calcined solids & 2.65 & 4.80 & 2.81 \\
\hline Nitrite, mg/kg slurry & mg/kg slurry & 20,500 & 4,205 & 6,550 \\
\hline Nitrate, mg/kg slurry & mg/kg slurry & 15,400 & 3,470 & 4,550 \\
\hline TIC, mg/kg slurry & $\mathrm{mg} / \mathrm{kg}$ slurry & 2,510 & 1.153 & 1,060 \\
\hline Total Base, mol/L slurry & $\mathrm{mol} / \mathrm{L}$ slurry to $\mathrm{pH}=7$ & 0.316 & 1.269 & $1.50 / 2.1^{\mathrm{C}}$ \\
\hline $\mathrm{pH}$ & & 12.6 & NA & $>13$ \\
\hline
\end{tabular}

${ }^{a}$ See Reference 15.

b SB5-4 and SB5-5 designate the same SRAT receipt (sludge) material. SB5-4 and SB5-5 utilize different acid addition amounts (see Table 3-8 and Table 3-9) and therefore different SRAT product results (see Table 3-10).

c Two values for total base are presented here. The first is a titration of diluted slurry. The second is a titration of undiluted slurry. See the preceding paragraph for details.

As can be seen from the above table, there are some striking differences in the SC-3 (pre aluminum dissolution) and SC-4 (post aluminum dissolution) SRAT receipt samples caused primarily by the addition of caustic for aluminum dissolution. For the acid calculation, the most significant change is the replacement of nitrite and nitrate by hydroxide. Another significant difference between pre and post aluminum dissolution sludge is the aluminum concentration in the SRAT receipt supernate - the current DWPF feed (Tank 40) contains $0.008 \mathrm{M} \mathrm{Al}^{16}$, while the SC-4 SRAT receipt sample was $0.35 \mathrm{M}$ (Table 3-2). Both of these differences impact the SRAT receipt total base measurement, a major contributor to the acid demand calculation. It is not clear at this time how the additional hydroxide and the aluminum in the supernate impact the total base measurement. Based on the results of the SC-4 SRAT cycle (see Section 3.5), it appears that a titration of diluted slurry under calculates acid demand. Further studies of the titration methodology or an acid calculation less dependant on total base are needed. 
Table 3-8. Acid Calculation Inputs of the Washed Post Aluminum Dissolution Tank 51 Sample (SC-4 SRAT Receipt) and the Corresponding Non Rad Simulant SRAT Receipt (SB5-4 \& -5) With Comparison to a Pre Aluminum Dissolution SRAT Receipt Sample (SC-3)

\begin{tabular}{|c|c|c|c|c|c|}
\hline Input/Assumption & Unit & SC- $3^{\mathrm{a}}$ & SB5-4 & SB5-5 & SC-4 \\
\hline $\begin{array}{l}\text { Conversion of Nitrite to Nitrate } \\
\text { in SRAT Cycle }\end{array}$ & gmol $\mathrm{NO}_{3}{ }^{-} / 100 \mathrm{gmol} \mathrm{NO}_{2}{ }^{-}$ & 15 & 30 & 30 & 15 \\
\hline $\begin{array}{l}\text { Destruction of Nitrite in SRAT } \\
\text { and SME cycle }\end{array}$ & $\%$ of starting nitrite & 100 & 100 & 100 & 100 \\
\hline $\begin{array}{l}\text { Destruction of Formic acid } \\
\text { charged in SRAT }\end{array}$ & $\%$ & 25 & 33 & 33 & 25 \\
\hline Destruction of oxalate charged & $\%$ & NA & 50 & 50 & NA \\
\hline $\begin{array}{l}\text { Percent Acid in Excess } \\
\text { Stoichiometric Ratio } \\
\end{array}$ & $\%$ & 130 & 115 & 130 & 115 \\
\hline SRAT Product Target Solids & $\%$ & 20 & 15 & 15 & 20 \\
\hline Predicted or Target REDOX & $\mathrm{Fe}^{+2} / \Sigma \mathrm{Fe}$ & $0.21^{b}$ & 0.20 & 0.20 & 0.20 \\
\hline $\begin{array}{l}\text { Number of basis antifoam } \\
\text { additions added during SRAT } \\
\text { cycle }\end{array}$ & & 8 & 8 & 8 & 11 \\
\hline $\begin{array}{l}\text { Destruction of Formic acid in } \\
\text { SME }\end{array}$ & $\%$ & 0 & NA & NA & 0 \\
\hline Destruction of Nitrate in SME & $\%$ & 0 & NA & NA & 0 \\
\hline Assumed SME density & $\mathrm{kg} / \mathrm{L}$ & 1.45 & NA & NA & 1.45 \\
\hline $\begin{array}{l}\text { No. of basis antifoam additions } \\
\text { added during SME cycle }\end{array}$ & & 3 & NA & NA & 3 \\
\hline $\begin{array}{l}\text { Sludge Oxide Contribution in } \\
\text { SME (Waste Loading) }\end{array}$ & $\%$ & 30 & NA & NA & 30 \\
\hline Target SME Solids total Wt\% & $\mathrm{Wt} \%$ & 45 & NA & NA & 45 \\
\hline
\end{tabular}

${ }^{a}$ See Reference 15.

${ }^{\mathrm{b}}$ A specific split between formic and nitric acid was used for this run. That is, this is a calculated (predicted) REDOX value. Note that typically a REDOX value is chosen, and the acid calculation uses this as input to determine the split between nitric and formic acids.

The primary results of the acid calculation (the acid requirements) are presented in Table 3-9. Note that for the SC-4 SRAT cycle, two stoichiometric acid amounts are given based on the two titration results (see discussion above). The actual amount of acid added for the SC-4 cycle was based on the lower total base result. Acid amounts using both titration results were calculated and prepared. At the conclusion of formic acid addition, the SRAT pH was measured and found to be less than 4. Based on this measurement, it was determined that no additional acid was required. However, post cycle analytical results (nitrite and mercury in the SRAT product) indicate that insufficient acid was added. These results are presented in Section 3.5. 
Table 3-9. SRAT Cycle Acid Requirements

\begin{tabular}{|l|c|c|c|c|}
\hline & SC-3 $^{\text {a }}$ & SB5-4 & SB5-5 & SC-4 \\
\hline $\begin{array}{c}\text { Calculated Stoich. Acid, } \\
\text { moles/L }\end{array}$ & 1.30 & 1.53 & 1.53 & $1.99 / 2.59^{\text {b }}$ \\
\hline $\begin{array}{c}\text { Actual Acid Added, } \\
\text { moles/L }\end{array}$ & 1.46 & 1.98 & 2.23 & 2.29 \\
\hline $\begin{array}{c}\text { Ratio of Formic Acid to } \\
\text { Total Acid }\end{array}$ & 0.99 & 0.85 & 0.84 & 0.83 \\
\hline
\end{tabular}

${ }^{\text {a }}$ See Reference 15.

${ }^{\mathrm{b}}$ The two values correspond to $1.5 \mathrm{~mol}$ total base/L and $2.1 \mathrm{~mol}$ total base/L, respectively. The actual amount of acid added was $115 \%$ of the lower acid amount.

\subsection{CPC Processing Results}

Results of the two simulant runs SB5-4 and SB5-5 and the Shielded Cells SC-4 run are presented here, along with the previously published SC-3 (Tank 51 pre aluminum dissolution) ${ }^{15}$ run for comparison. The simulant runs were performed to provide input (e.g., excess acid amount) for the SC-4 run. Comparing these simulant results to the SC-4 results show that the simulant was not a good representation of the actual waste. SC-3 results are given to show the impacts of aluminum dissolution on CPC processing. Note that the discussion below is primarily focused on the SC-4 post aluminum dissolution in-Cells run with the actual Tank 51 material.

\subsubsection{SRAT Cycle Processing Observations}

There were no significant processing problems during the SC-4 SRAT cycle other than foaming. There were no difficulties in mixing or heating the sludge slurry, but the sludge was prone to foaming. The following antifoam addition strategy was used:

- 200 ppm addition prior to starting the cycle

- 100 ppm addition between nitric and formic acid additions

- 500 ppm addition after acid addition, prior to boiling

- 100 ppm addition every 8 hours thereafter

The above strategy contains an additional 100 ppm addition (between nitric and formic acid additions) compared to recent antifoam addition strategies. It should be noted that the above strategy is equivalent to DWPF's current addition strategy. In the three previous runs containing Tank 51 - SB4, antifoam was needed shortly after formic acid was begun. ${ }^{14,15}$ It was decided to add the antifoam before it was needed and to help ensure against a foam over in this run.

Even with the extra antifoam prior to formic acid addition, an additional $100 \mathrm{ppm}$ of antifoam was needed during the final third of formic acid addition. Also, an extra $100 \mathrm{ppm}$ of antifoam was added with the scheduled antifoam addition eight hours after formic acid addition.

\subsubsection{SRAT Cycle Sample Results}

A sample was pulled at the conclusion of the SRAT cycle. The total solids, anions, and mercury analysis were performed. These results are presented in Table 3-10, along with the results of the SC-3 SRAT cycle and the simulant SRAT cycles for comparison. As shown in the table, nitrite was not adequately 
destroyed to less than $1,000 \mathrm{mg} / \mathrm{kg}$, and mercury was not removed to below the DWPF requirement of $0.45 \%$ of the total solids.

It should also be noted that the simulant used for the SB5-4 and SB5-5 runs did not adequately represent the radioactive waste sample. With less acid added per liter of slurry (both runs), the goals of destroying nitrite and removing mercury were accomplished. This may be related to the soluble versus insoluble aluminum in the simulant and radioactive waste. In the simulant, all the aluminum was soluble, while only $8 \%$ of the aluminum was soluble in the SC-4 SRAT receipt sample. This difference was likely due to different forms of aluminum in the simulant compared to the aluminum in the radioactive material. Development of a more representative simulant may be necessary to develop an understanding of how aluminum affects SRAT receipt acid demand.

Table 3-10. SRAT Product Characterization Results

\begin{tabular}{|l|c|c|c|c|}
\hline & SC-3 $^{\mathbf{a}}$ & SB5-4 & SB5-5 & SC-4 \\
\hline Wt \% Total Solids (slurry basis) & 21.3 & 15.6 & 15.2 & 22.6 \\
\hline Wt \% Insoluble Solids (slurry basis) & 11.1 & 5.77 & 5.77 & 10.0 \\
\hline Wt \% Soluble Solids (slurry basis) & 10.2 & 6.50 & 9.43 & 12.6 \\
\hline Slurry Density (g/mL) & 1.22 & 1.08 & 1.07 & 1.17 \\
\hline Supernate Density (g/mL) & 1.09 & $\mathrm{NM}$ & $\mathrm{NM}$ & 1.10 \\
\hline Formate (mg/kg slurry) & 33,400 & 47,900 & 50,700 & 51,900 \\
\hline Nitrite (mg/kg slurry) & $<1,000$ & $<100$ & $<100$ & 2,710 \\
\hline Nitrate (mg/kg slurry) & 26,100 & 16,950 & 18,200 & 25,000 \\
\hline Mercury (wt \% of total solids) & 0.23 & $<0.01$ & $<0.01$ & 0.79 \\
\hline
\end{tabular}

${ }^{a}$ See Reference 15

\subsubsection{SRAT Cycle Anion Destruction and Conversion}

Inputs to the acid calculation include formate destruction and conversion of nitrite to nitrate. Presented in Table 3-11 is a comparison between these assumed values (based on simulant runs) and measured results. As can be seen in the table, formate destruction and nitrite destruction were lower than predicted for SC-4. Also, the high nitrite to nitrate conversion shows that most of the destroyed nitrite was converted to nitrate. These results show that the acid added for the SC-4 run was lower than needed for the SRAT cycle. This is confirmed in the offgas data given below.

Table 3-11. Comparison of Assumed and Measured Anion Destruction and Conversion in the SRAT Cycles

\begin{tabular}{|l|l|c|c|c|c|}
\hline & & SC-3 & SB5-4 & SB5-5 & SC-4 \\
\hline \multirow{2}{*}{ Formate Destruction (\%) } & Assumed & 25 & 33 & 33 & 25 \\
\cline { 2 - 6 } & Measured & 21 & 25 & 23.6 & 14.3 \\
\hline \multirow{2}{*}{ Nitrite Destruction (\%) } & Assumed & 100 & 100 & 100 & 100 \\
\cline { 2 - 6 } & Measured & 100 & $>99.5$ & $>99.5$ & 51 \\
\hline $\begin{array}{l}\text { Nitrite to Nitrate Conversion (\% of } \\
\text { destroyed nitrite) }\end{array}$ & Assumed & 15 & 30 & 30 & 15 \\
\cline { 2 - 6 } & Measured & 37 & 22.8 & 33.2 & 94 \\
\hline
\end{tabular}




\subsubsection{SRAT Cycle Offgas Analysis}

Offgas data for the SC-4 SRAT cycle, along with the SC-3 offgas data, are presented in the following figures. ${ }^{* *}$ The offgas data, specifically the nitrous oxide data, suggest the under-addition of acid. The SC3 nitrous oxide data is typical. As acid is added to sludge, carbon dioxide is generated as $\mathrm{pH}$ drops and carbonate is destroyed. Acid added to the sludge also destroys nitrite, producing $\mathrm{NO}_{\mathrm{x}}$ (note that only nitrous oxide is measured in SRNL simulations). The majority of nitrite destruction is complete near the end of acid addition, resulting in a drop of measured nitrous oxide. Hydrogen generation from the noble metals-catalyzed decomposition of excess formic acid typically begins one to three hours after the nitrous oxide peak (i.e., after nitrite destruction ${ }^{17}$ ).

The SC-4 run does not show this typical behavior. There was no extreme peak for nitrous oxide generation, and it is detected throughout the cycle at a significant rate ( $2.5 \mathrm{lb} / \mathrm{hr}$, DWPF scale), showing that nitrite was present in the SRAT contents throughout the cycle. SRAT product analytical results confirm this (see Table 3-10). Also, the low hydrogen generation suggests that there was little excess acid for hydrogen generation.

It is interesting to note the effect of mixing and foaming on offgas. After acid addition was complete, the SRAT vessel was allowed to cool to approximately $80^{\circ} \mathrm{C}$ and mixing was stopped to measure the $\mathrm{pH}$. The spike in gas generation at approximately two hours corresponds to the resumption of mixing when gas retained in the sludge slurry was quickly released. Note that the mixing was stopped for approximately 30 minutes.

Large amounts of foam could be seen in the SRAT vessel during the second offgas spike (approximately 24.5 hours after acid addition, and 8 hours after the previous antifoam addition). It may be possible to use offgas data as an indication of foaming. However, this indication may not be soon enough in the DWPF to prevent a foam-over.

\footnotetext{
${ }^{* *}$ SB5-4 and SB5-5 are presented in Appendix D. In both runs, hydrogen generation was well below DWPF limits, indicating the recommended acid addition strategy for SC-4 would not exceed DWPF limits.
} 


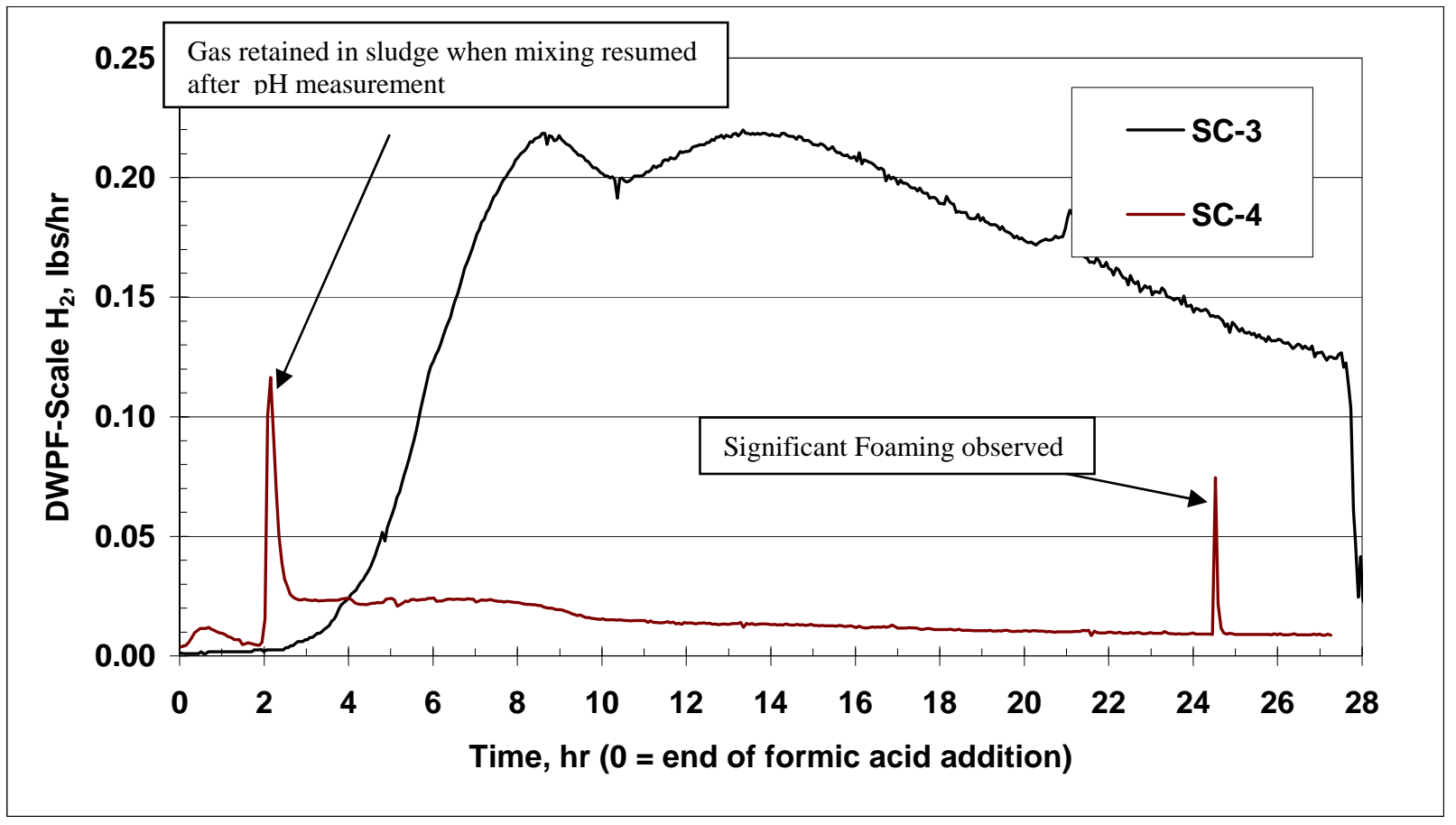

Figure 3-2. Hydrogen Generation During SC-3 and SC-4 SRAT Cycles

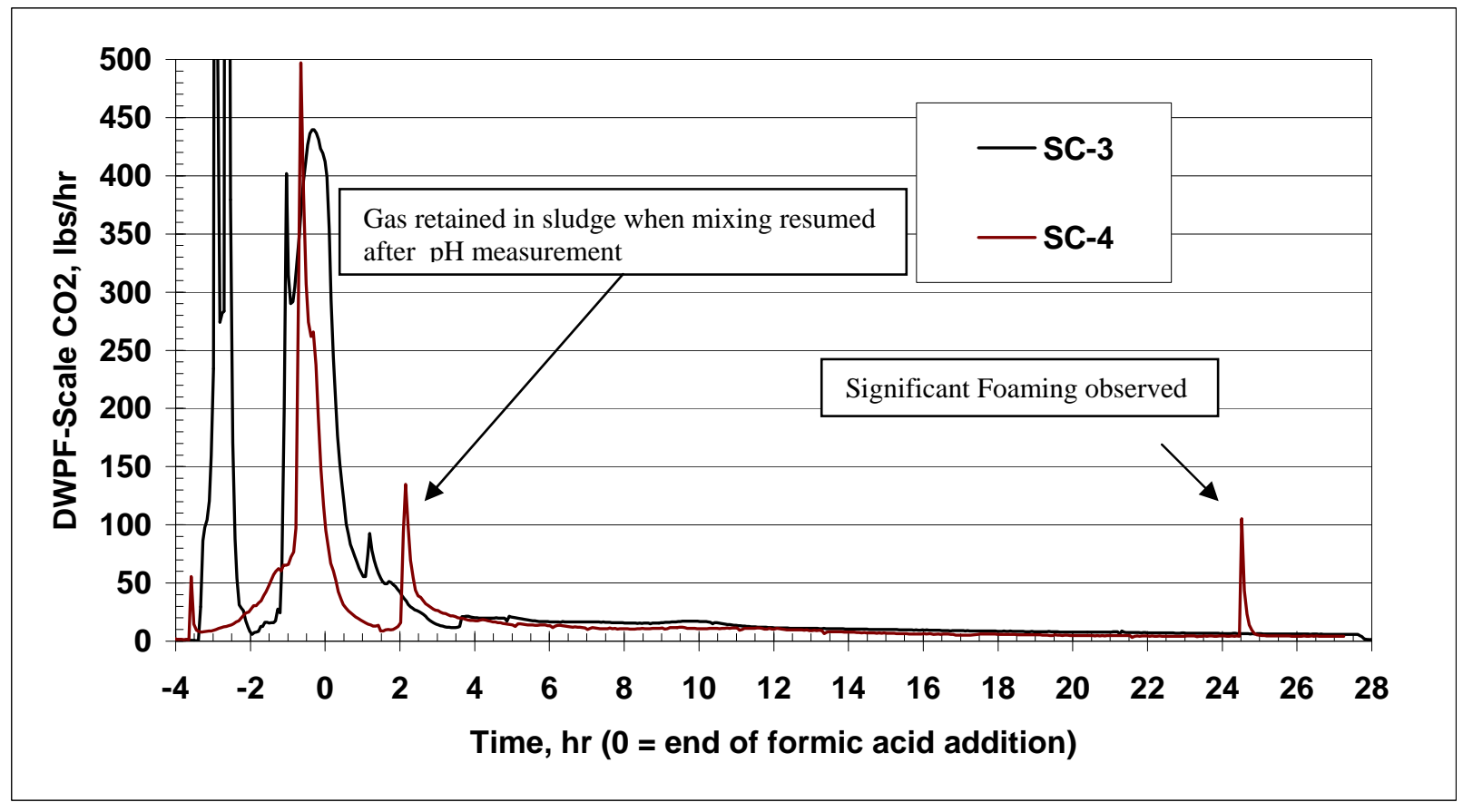

Figure 3-3. Carbon Dioxide Generation During SC-3 and SC-4 SRAT Cycles 
WSRC-STI-2008-00086

Revision 0

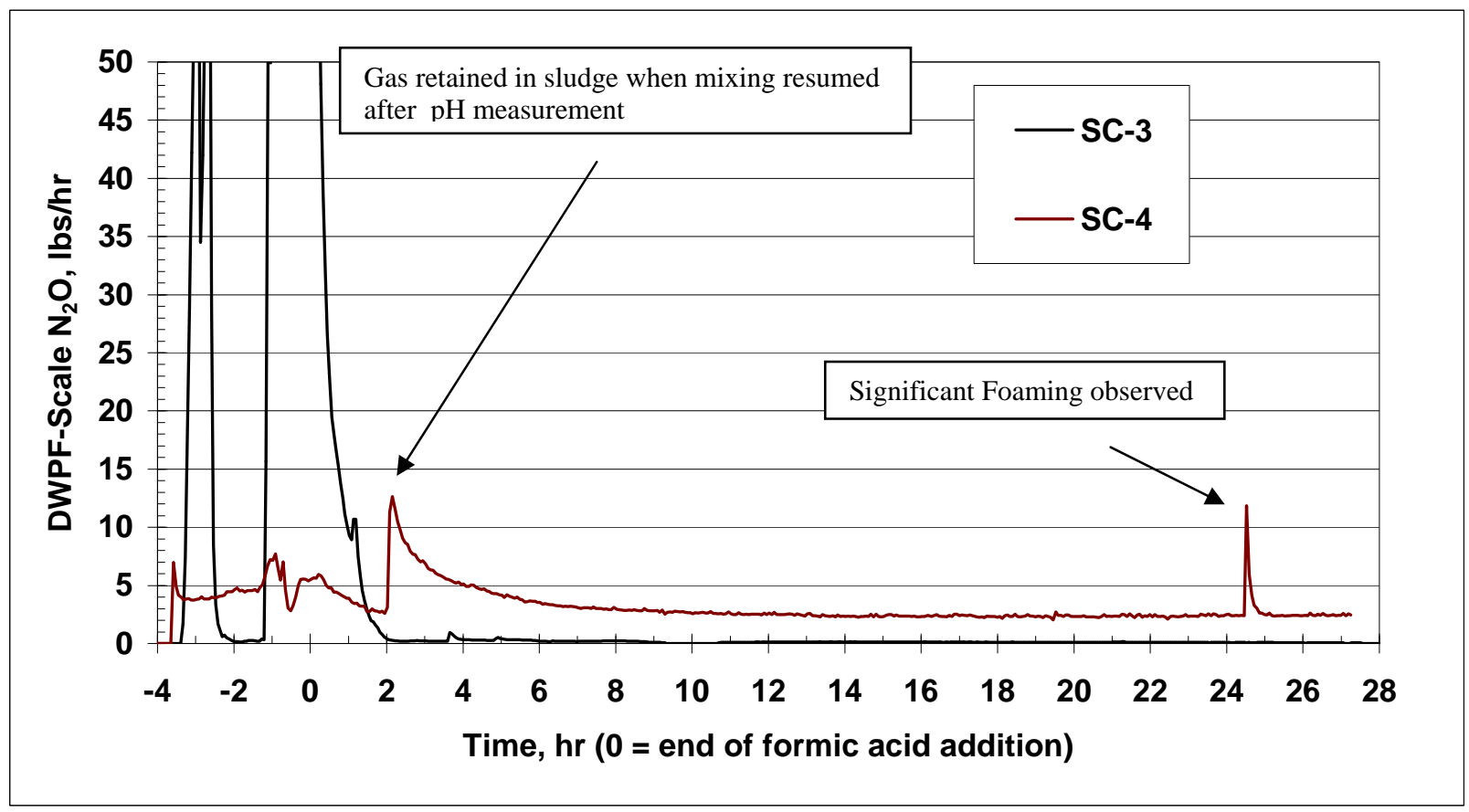

Figure 3-4. Nitrous Oxide Generation During SC-3 and SC-4 SRAT Cycles

\subsubsection{SME Processing Observations}

There were no processing issues with the SC-4 SME cycle; vessel contents mixed well, and there were no problems achieving target boil up rates. The SME contents however were prone to foaming. Antifoam was needed every 3 to 5 hours during the cycle.

\subsubsection{SME Cycle Sample Results}

Samples were collected at the conclusion of the SME cycle and analyzed for total solids, anions, and total organic carbon. Total solids are higher than the target of $45 \%$. This is likely due to small losses of water from leaks and losses from carbonate destruction and other reactions not accounted for in the mass balance used to calculate dewater amount. Even with this higher total solids, there were no issues with mixing or heating. Results are given in Table 3-12, along with the SC-3 Cycle. Note that a SME cycle was not completed with the simulant. 
WSRC-STI-2008-00086

Revision 0

Table 3-12. SME Product Weight Percent Solids and Densities

\begin{tabular}{|l|c|c|}
\hline Physical Property & SC-3 & SC-4 \\
\hline Wt \% Total Solids (slurry basis) & 49.6 & 48.3 \\
\hline Wt \% Insoluble Solids (slurry basis) & 40.8 & 37.6 \\
\hline Wt \% Soluble Solids (slurry basis) & 9.2 & 10.8 \\
\hline Slurry Density (g/mL) & 1.44 & 1.46 \\
\hline Supernate Density (g/mL) & 1.12 & 1.13 \\
\hline Formate (mg/kg slurry) & 36,000 & 46,600 \\
\hline Nitrite (mg/kg slurry) & $<1,000$ & 1,360 \\
\hline Nitrate (mg/kg slurry) & 30,400 & 22,400 \\
\hline Total Organic Carbon (mg/kg slurry) & NA & 15,300 \\
\hline
\end{tabular}

\subsubsection{SME Cycle Anion Destruction}

Inputs to the acid calculation for the SME cycle include formate and nitrate destruction. Presented in Table 3-13 is a comparison between these assumptions and measured results for SC-3 and SC-4. These results provide further evidence that acid addition in the SRAT cycle was inadequate: there was no measurable formate or nitrate destruction in the SME cycle.

Table 3-13. Comparison of Assumed and Measured Anion Destruction and Conversion in the SME Cycles

\begin{tabular}{|l|l|c|c|}
\hline & & SC-3 & SC-4 \\
\hline \multirow{2}{*}{ Formate Destruction (\%) } & Assumed & 0 & 0 \\
\cline { 2 - 4 } & Measured & 26 & 0 \\
\hline \multirow{2}{*}{ Nitrate Destruction (\%) } & Assumed & 0 & 0 \\
\cline { 2 - 4 } & Measured & 4 & 0 \\
\hline Nitrite Destruction (\%) & Measured & NA & 40 \\
\hline
\end{tabular}

\subsubsection{SME Cycle Offgas Data}

SME cycle hydrogen generation data for the SC-4 run (with the SC-3 SME cycle) is presented in Figure 3-5. The low hydrogen generation again shows that acid was under-added in the SC-4 CPC processing. 
WSRC-STI-2008-00086

Revision 0

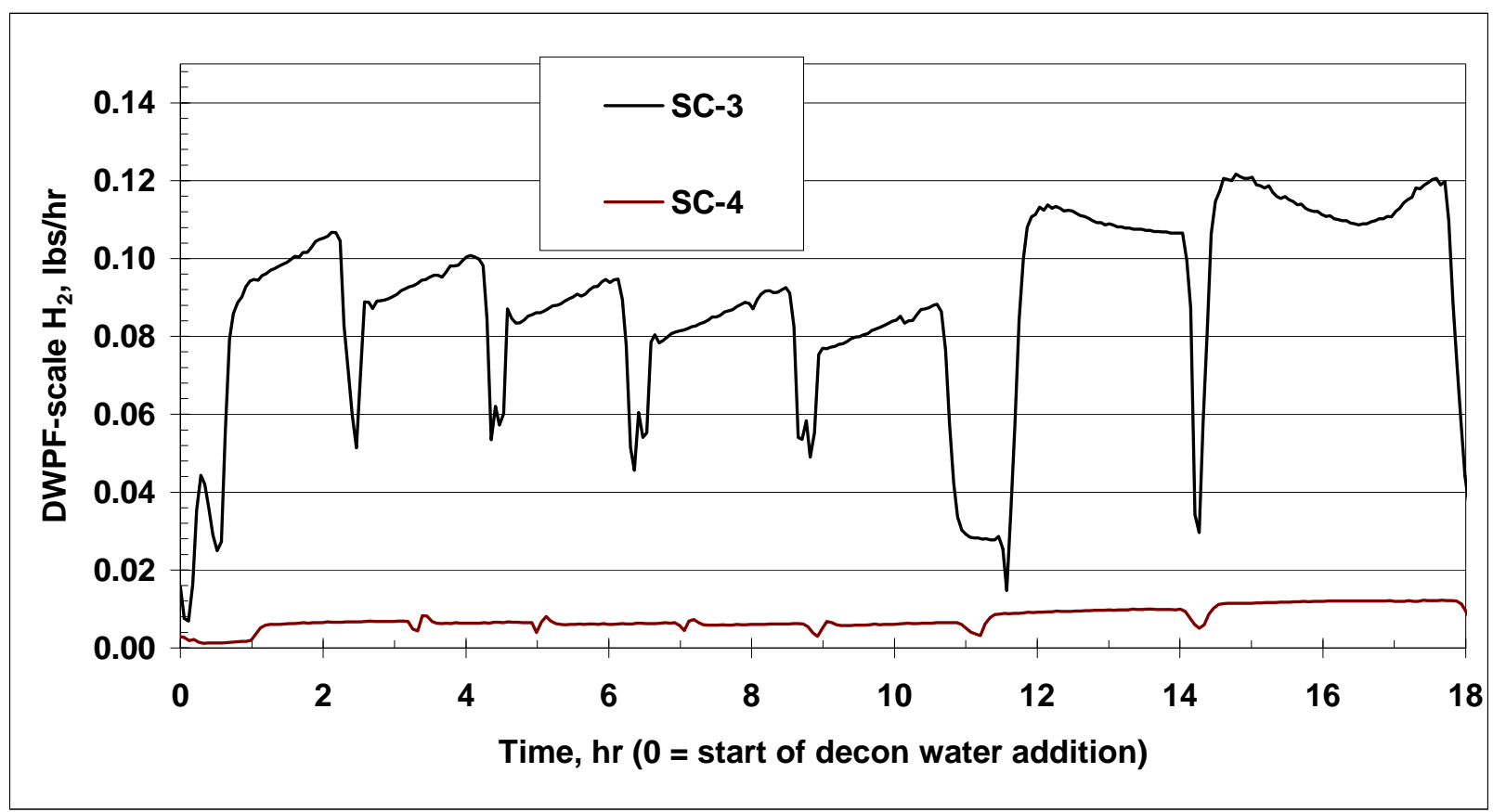

Figure 3-5. SME Cycle Hydrogen Generation Data

\subsection{Rheology}

The rheological properties are summarized in Table 3-14, with flow curves given in Appendix C. A comparison between the As-received, post aluminum dissolution and washed samples indicate that the aluminum dissolution process impacts the rheological properties of the Tank 51 sludge. In all these cases, the downstream materials were more viscous and the concentration of insoluble solids less than that of the starting material. The ability to pump the washed material, at a given solids concentration, from Tank 51 to Tank 40 must be considered ${ }^{18}$ when concentrating the contents in Tank 51. The SC-4 SRAT and SME products exceed (i.e., do not meet) the design basis rheological properties, ${ }^{19}$ but due to the probable under addition of acid, these rheological results must be used with caution. These results are compared to the SC-3 SRAT and SME products results, which are also provided in Table 3-14. The SC-4 material is rheologically thicker than the SC-3 material. 
WSRC-STI-2008-00086

Revision 0

Table 3-14. Rheological Properties of As-Received, Al Dissolved, Washed and SRAT/SME Products

\begin{tabular}{|c|c|c|c|c|c|}
\hline Sample & $\begin{array}{c}\text { Yield } \\
\text { Stress (Pa) }\end{array}$ & $\begin{array}{c}\text { Plastic } \\
\text { Viscosity (cP) }\end{array}$ & $\begin{array}{c}\text { Wt\% Total } \\
\text { Solids }\end{array}$ & $\begin{array}{c}\text { Wt\% Insoluble } \\
\text { Solids }\end{array}$ & $\begin{array}{c}\text { Slurry Density } \\
\text { (g/ml) }\end{array}$ \\
\hline Tank 51, As-Rcvd & 5.83 & 7.64 & 15.50 & 9.39 & 1.08 \\
\hline Post Al Dissolution & 9.24 & 19.32 & 27.98 & 6.44 & 1.27 \\
\hline Wash 1 & 4.70 & 8.97 & 18.46 & 6.52 & 1.19 \\
\hline Wash 2/Decant 2a & 7.21 & 9.83 & 16.27 & 8.87 & 1.14 \\
\hline $\begin{array}{c}\text { Wash 2/Decant 2b, SC-4 SRAT } \\
\text { Rcpt }\end{array}$ & 19.92 & 18.22 & 19.12 & 11.96 & 1.20 \\
\hline SC-4-SRAT Product & 13.35 & 16.47 & 22.63 & 10.02 & 1.17 \\
\hline SC-4-SME Product & 21.59 & 29.15 & 48.35 & 37.59 & 1.46 \\
\hline SC-3-SRAT Product & 7.21 & 10.16 & 21.30 & 11.10 & 1.22 \\
\hline SC-3-SME Product & 10.88 & 19.80 & 49.60 & 40.80 & 1.44 \\
\hline \hline \multicolumn{7}{|c|}{ DWPF Design Basis ${ }^{19}$} & - & - & 1.20 \\
\hline \hline SRAT/SME - Minimum & 2.5 & 10 & - & - & 1.43 \\
\hline SRAT/SME - Maximum & 15.0 & 40 & - & \\
\hline
\end{tabular}




\subsection{CONCLUSIONS}

The purpose of this task was to determine potential downstream impacts of aluminum dissolution so technical issues could be identified before the start of SB5 processing using an SRNL prepared post aluminum dissolution sludge sample. The potential downstream impacts assessed include the Tank Farm sludge washing and concentration process and the DWPF Chemical Process Cell.

The impact of aluminum dissolution on sludge settling is not clear. Settling during prototypical sludge washing and concentration steps did not follow a trend. Compared to the post aluminum dissolution sample, settling after the first wash was slower, but settling after the second wash was faster.

Aluminum dissolution did impact sludge rheology. A comparison between the As-received, post aluminum dissolution and washed samples indicate that the downstream materials were more viscous and the concentration of insoluble solids less than that of the starting material. This increase in viscosity may impact Tank 51 transfers to Tank 40. It also has the potential to impact processing in DWPF if the SRAT process does not reduce the slurry yield stress as seen with other DWPF sludge batches.

DWPF CPC processing was not successfully completed on the aluminum dissolved sludge due to the acid addition for the SRAT cycle being under-calculated and, thus, under-added. Although the sludge was rheologically thick throughout the SRAT and SME cycles, this may have been due to the under-addition of acid. It should be noted that one of the purposes of acid addition during CPC processing is to adjust rheological properties (i.e., reduce yield stress).

Aluminum dissolution did impact analyses of the SRAT receipt material. Two methods for determining total base yielded significantly different results. The high hydroxide content and the relatively high soluble aluminum content of the washed post aluminum dissolution sludge likely contributed to this difference and the ultimate under addition of acid. It should be noted that the simulant used to provide input for the SC-4 SRAT cycle was an inadequate representation of the waste in terms of acid demand due to the inability to replicate the form of aluminum in the sludge and supernate. 


\subsection{RECOMMENDATIONS}

Sludge settling and rheology during washing of the forthcoming Sludge Batch 5 qualification sample should be monitored closely and communicated to the Tank Farm.

It is recommended that SRNL receive a sample of Tank 51 after all chemical additions are complete and prior to the final Sludge Batch 5 decant for rheological assessment. Rheology versus wt\% insoluble solids will be performed to determine the maximum amount of decant prior to the Tank 51 to Tank 40 transfer.

As a result of the problem with measuring total base and subsequently under-calculating acid for the DWPF CPC processing of the post aluminum dissolution sludge, the following is recommended:

- Perform studies to develop understanding of how the sludge titrates (i.e., why different titration methods yield different results).

- Develop simulants that better match the properties of post aluminum dissolution sludge.

- Continue work on developing an acid calculation less dependant on the total base measurement. 


\subsection{REFERENCES}

1. Hay, M. S.; Pareizs, J. M.; Bannochie, C. J.; Stone, M. E.; Click, D. R.; McCabe, D. J. Characterization and Aluminum Dissolution Demonstration With A 3 Liter Tank 51H Sample; WSRC-STI-2007-00697, Rev. 0; Savannah River National Laboratory: Aiken, SC, 2008.

2. Bannochie, C. J.; Hay, M. H.; Pareizs, J. M.; Peeler, D. K. Technology Demonstration of Sludge Mass Reduction via Aluminum Dissolution: Task Technical and Quality Assurance Plan; TTQAP WSRCRP-2007-00512, Rev. 0; Savannah River National Lab: 2007.

3. Bannochie, C. J.; Hay, M. S. Analytical Study Plan: Demonstration of Dissolution of Tank 51 Sludge; Analytical Study Plan WSRCRP-2007-00396, Rev. 2; Savannah River National Lab: Aiken, SC, 2007.

4. Process Science and Engineering Section Procedure Manual; Manual L29; Savannah River National Lab: Aiken, SC, 2007.

5. Analytical Development Procedures Manual; Manual L16; Savannah River National Laboratory: Aiken, SC.

6. Pike, J. A.; Gillam, J. M. Flowsheet for Aluminum Removal From Sludge Batch 5; LWO-PIT-200700042, Rev. 2; Aiken, 2007.

7. Stone, M. E. Lab-Scale CPC Equipment Set-up; Interoffice Memorandum SRNL-PSE-2006-00074; 2006.

8. Stone, M. E. SRAT Assembly for SB4 Shielded Cells Testing: SC-4; Inter-office memorandum SRNLPSE-2007-00277; Savannah River National Lab: Aiken, SC 29808, 2007.

9. SB5 Aluminum Dissolution II; Notebook WSRC-NB-2007-00144; Savannah River National Laboratory: Aiken, SC, 2007.

10. SB5 Aluminum Dissolution III; Notebook WSRC-NB-2007-00191; Savannah River National Laboratory: Aiken, SC, 2008.

11. Lambert, D. P. Acid Calculation Spreadsheet for DWPF Simulations, Revision 1; Inter-Office Memorandum SRNL-PSE-2006-00173; Savannah River National Laboratory: Aiken, SC, 2006.

12. Jantzen, C. M.; Zamecnik, J. R.; Koopman, D. C.; Herman, C. C.; Pickett, J. B. Electron Equivalents Model for Controlling Reduction-Oxidation ( REDOX) Equilibrium during High Level Waste (HLW) Vitrification; Technical Report WSRC-TR-2003-00126; Savannah River National Laboratory: Aiken, SC, 2003.

13. Darby, R., Chemical Engineering Fluid Mechanics, 2nd edition. Marcel Dekker: 2001.

14. Pareizs, J. M.; Bannochie, C. J.; Barnes, M. J.; Bibler, N. E.; Click, D. R.; Hansen, E. K.; Lambert, D. P.; Stone, M. E. Demonstration of the DWPF Flowsheet in the SRNL Shielded Cells in Support of Sludge Batch 4 Qualification; Technical Report WSRC-STI-2007-00053; Savannah River National Laboratory: Aiken, SC, 2007. 
WSRC-STI-2008-00086

Revision 0

15. Koopman, D. C.; Pareizs, J. M.; Lambert, D. P.; Bannochie, C. J. Sludge Batch 4 Follow-up

Qualification Studies to Evaluate Hydrogen Generation; Technical Report WSRC-STI-2007-00212;

Savannah River National Laboratory: Aiken, SC, 2007.

16. Bannochie, C. J. Tank 40 Final SB4 Chemical Characterization Results; Technical Report WSRCSTI-2007-00674; Savannah River National Laboratory: Aiken, SC, 2008.

17. King, R. B.; Bhattacharyya, N. K., Catalytic reactions of formate 4. A nitrite-promoted rhodium (III) catalyst for hydrogen generation from formic acid in aqueous solution. inorganica Chimica Acta 1995, 237, 65-69.

18. Hansen, E. K. Tank 51 Sludge Batch 4 Transfer to Tank 40; Technical Report WSRC-STI-200600218, Rev. 0; 2006.

19. Technical Data Summary For the DWPF, Part 3, Item 300 and Part 10, Item 230; DPSTD-80-38-2; Savannah River Site: Aiken, SC, 1980. 


\subsection{ACKNOWLEDGEMENTS}

The authors would like to recognize the invaluable support of the SRNL Shielded Cells technicians and management for the in-cells work; the ACTL technicians for assistance in equipment setup, reagent preparation, and consultation during the SRAT and SME cycles; S. H. Reboul for overseeing the apparatus fabrication and testing for the boiling evaluation; and the SRNL Glass Shop for providing glassware and other miscellaneous hardware. 


\section{APPENDIX A. SETTLING DATA FROM POST ALUMINUM DISSOLUTION WASHING}

NOTE:

Overall Volume $(m L)=$ Sludge Level $\times 176-129$

\begin{tabular}{|l|c|c|c|c|c|c|}
\hline Wash 1 & & & & & & \\
\hline Sludge Slurry Level & & 14.6 & Sludge Slurry Volume $(\mathrm{r}$ & 2440.6 & $\mathrm{~mL}$ \\
\hline & & & & & & \\
\hline Date/Time & $\begin{array}{c}\text { Settling } \\
\text { Time }(\mathrm{d})\end{array}$ & $\begin{array}{c}\text { Sludge } \\
\text { Level }\end{array}$ & $\begin{array}{c}\text { Sludge } \\
\text { Volume } \\
(\mathrm{mL})\end{array}$ & $\begin{array}{c}\text { Supernate } \\
\text { vol }(\mathrm{mL})\end{array}$ & $\begin{array}{c}\text { Sup vol } \\
\text { change } \\
(\mathrm{mL} / \mathrm{d})\end{array}$ & $\begin{array}{c}\text { Rel sludge } \\
\text { ht }\end{array}$ \\
\hline $10 / 16 / 200714: 45$ & 0.0 & 14.6 & 2,441 & 0 & & 1.00 \\
\hline $10 / 17 / 20076: 40$ & 0.7 & 13.4 & 2,229 & 211 & 318 & 0.92 \\
\hline $10 / 17 / 200715: 00$ & 1.0 & 13.0 & 2,159 & 282 & 203 & 0.89 \\
\hline $10 / 18 / 20077: 15$ & 1.7 & 12.7 & 2,106 & 334 & 78 & 0.87 \\
\hline $10 / 18 / 200714: 20$ & 2.0 & 12.3 & 2,036 & 405 & 239 & 0.84 \\
\hline $10 / 19 / 20076: 10$ & 2.6 & 11.5 & 1,895 & 546 & 213 & 0.79 \\
\hline $10 / 19 / 200710: 25$ & 2.8 & 11.2 & 1,842 & 598 & 298 & 0.77 \\
\hline $10 / 22 / 20076: 40$ & 5.7 & 9.4 & 1,525 & 915 & 111 & 0.64 \\
\hline $10 / 22 / 200715: 30$ & 6.0 & 9.3 & 1,508 & 933 & 48 & 0.64 \\
\hline $10 / 23 / 20077: 35$ & 6.7 & 9.0 & 1,455 & 986 & 79 & 0.62 \\
\hline $10 / 23 / 200713: 40$ & 7.0 & 9.0 & 1,455 & 986 & 0 & 0.62 \\
\hline $10 / 24 / 20076: 40$ & 7.7 & 8.8 & 1,420 & 1,021 & 50 & 0.60 \\
\hline $10 / 25 / 200710: 35$ & 8.8 & 8.6 & 1,385 & 1,056 & 30 & 0.59 \\
\hline $10 / 29 / 20077: 48$ & 12.7 & 8.5 & 1,367 & 1,074 & 5 & 0.58 \\
\hline $10 / 30 / 200714: 00$ & 14.0 & 8.1 & 1,297 & 1,144 & 56 & 0.55 \\
\hline $10 / 31 / 20077: 55$ & 14.7 & 8.0 & 1,279 & 1,162 & 24 & 0.55 \\
\hline
\end{tabular}

\begin{tabular}{|c|c|c|c|c|c|c|}
\hline Wash 2 & & & & & & \\
\hline Sludge Slurry Leve & & 14.8 & Sludge Slu & ry Volume & 2475.8 & $\mathrm{~mL}$ \\
\hline Date/Time & $\begin{array}{l}\text { Settling Time } \\
\text { (d) }\end{array}$ & $\begin{array}{l}\text { Sludge } \\
\text { Level }\end{array}$ & $\begin{array}{l}\text { Sludge } \\
\text { Volume } \\
(\mathrm{mL})\end{array}$ & $\begin{array}{c}\text { Supernate } \\
\text { vol }(\mathrm{mL})\end{array}$ & $\begin{array}{l}\text { Sup vol } \\
\text { change } \\
(\mathrm{mL} / \mathrm{d})\end{array}$ & $\begin{array}{c}\text { Rel sludge } \\
\text { ht }\end{array}$ \\
\hline 11/6/2007 13:30 & 0.0 & 14.8 & 2,476 & 0 & & 1 \\
\hline $11 / 6 / 2007$ 15:45 & 0.1 & 14.7 & 2,458 & 18 & 188 & 0.99 \\
\hline 11/7/2007 15:40 & 1.1 & 8.7 & 1,402 & 1,074 & 1060 & 0.59 \\
\hline 11/8/2007 6:40 & 1.7 & 8.4 & 1,349 & 1,126 & 84 & 0.57 \\
\hline 11/8/2007 15:00 & 2.1 & 8.2 & 1,314 & 1,162 & 101 & 0.55 \\
\hline 11/9/2007 11:15 & 2.9 & 7.9 & 1,261 & 1,214 & 63 & 0.53 \\
\hline 11/12/2007 6:35 & 5.7 & 7.8 & 1,244 & 1,232 & 19 & 0.53 \\
\hline 11/12/2007 16:15 & 6.1 & 7.8 & 1,244 & 1,232 & 0 & 0.53 \\
\hline 11/13/2007 6:40 & 6.7 & 7.8 & 1,244 & 1,232 & 0 & 0.53 \\
\hline
\end{tabular}




\section{APPENDIX B. CALCULATION OF ALUMINUM AND SODIUM REMOVAL USING IRON RATIOS}

Calculation inputs and results

\begin{tabular}{|r|r|r|r|r|}
\hline & A & \multicolumn{1}{|c|}{ B } & \multicolumn{1}{|c|}{ C } & \multicolumn{1}{c|}{ D } \\
\hline 1 & & & & \\
\hline 2 & & As-Receive After Al Diss & After Wash \\
\hline 3 & $\mathrm{Al} \%$ of total solids & 15.6 & 8.92 & 13.9 \\
\hline 4 & $\mathrm{Fe} \%$ of total solids & 7.27 & 5.26 & 9.97 \\
\hline 5 & $\mathrm{Na} \%$ of total solids & 14.5 & 35.4 & 22.6 \\
\hline 6 & $\mathrm{Al} / \mathrm{Fe}$ & 2.15 & 1.70 & 1.39 \\
\hline 7 & $\mathrm{Na} / \mathrm{Fe}$ & 1.99 & 6.73 & 2.27 \\
\hline 8 & \%Al removed by diss & & & $21 \%$ \\
\hline 9 & & & & $14 \%$ \\
\hline 10 & \% Al removed by washing & & & $35 \%$ \\
\hline 11 & Total \% Al removed & & & \\
\hline 12 & & & & $66 \%$ \\
\hline 13 & \%Na removed in washing & & $14 \%$ \\
\hline 14 & Overall \% Na increase & & & \\
\hline
\end{tabular}

Inputs and formulas

\begin{tabular}{|c|c|c|c|c|}
\hline & A & $\mathrm{B}$ & $\mathrm{C}$ & $\mathrm{D}$ \\
\hline 1 & & & & \\
\hline 2 & & As-Received Tank 51 & After Al Diss & After Washing \\
\hline 3 & Al \% of total solids & 15.6 & 8.92 & 13.9 \\
\hline 4 & Fe $\%$ of total solids & 7.27 & 5.26 & 9.97 \\
\hline 5 & $\mathrm{Na} \%$ of total solids & 14.5 & 35.4 & 22.6 \\
\hline 6 & & & & \\
\hline 7 & $\mathrm{Al} / \mathrm{Fe}$ & $=\mathrm{B} 3 / \mathrm{B} 4$ & $=\mathrm{C} 3 / \mathrm{C} 4$ & $=\mathrm{D} 3 / \mathrm{D} 4$ \\
\hline 8 & $\mathrm{Na} / \mathrm{Fe}$ & $=\mathrm{B} 5 / \mathrm{B} 4$ & $=\mathrm{C} 5 / \mathrm{C} 4$ & $=\mathrm{D} 5 / \mathrm{D} 4$ \\
\hline 9 & \%Al removed by diss & & & $=(\mathrm{B} 7-\mathrm{C} 7) / \mathrm{B} 7$ \\
\hline 10 & $\%$ Al removed by washing & & & $=((\mathrm{C} 7-\mathrm{D} 7)) / \mathrm{B} 7$ \\
\hline 11 & Total \% Al removed & & & $=$ SUM(D9:D10) \\
\hline 12 & & & & \\
\hline 13 & $\% \mathrm{Na}$ removed in washing & & & $=(\mathrm{C} 8-\mathrm{D} 8) / \mathrm{C} 8$ \\
\hline 14 & Overall \% $\mathrm{Na}$ increase & & & $=(\mathrm{D} 8-\mathrm{B} 8) / \mathrm{B} 8$ \\
\hline
\end{tabular}




\section{APPENDIX C. RHEOLOGICAL CHARTS AND FLOW CURVES}

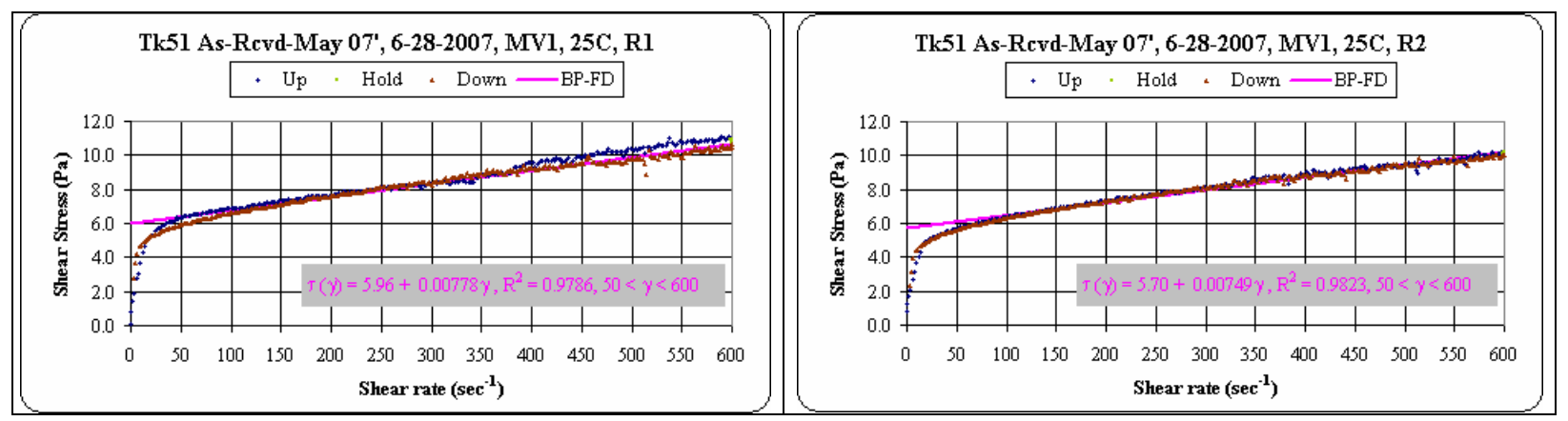

Figure C - 1 Tank 51, As-Received, May 2007, Flow Curve

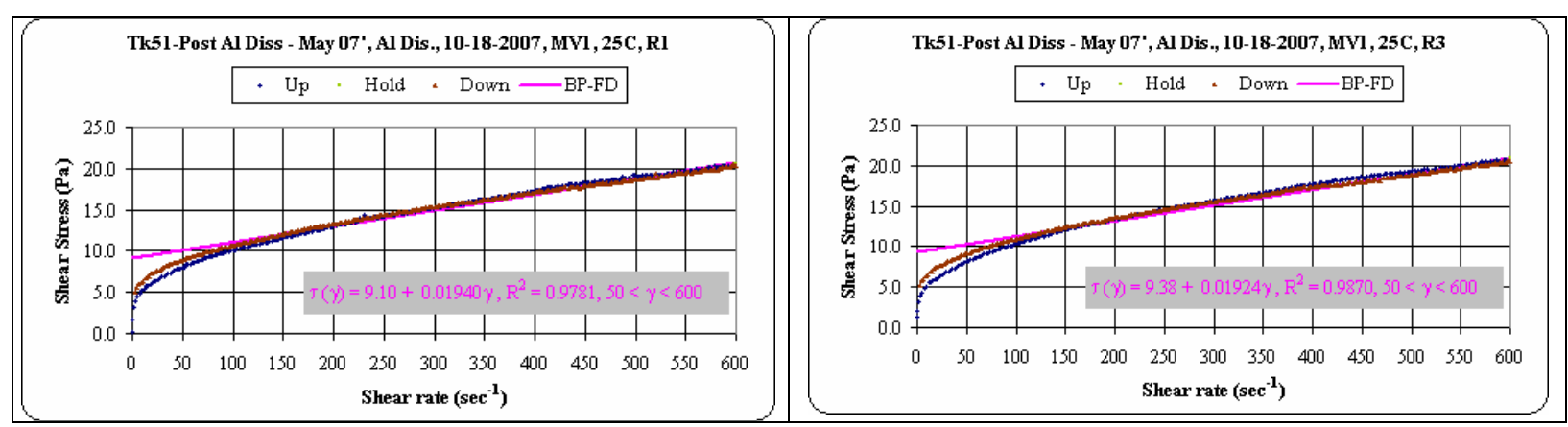

Figure C - 2 Tank 51, SRNL Post Aluminum Dissolution, Flow Curve

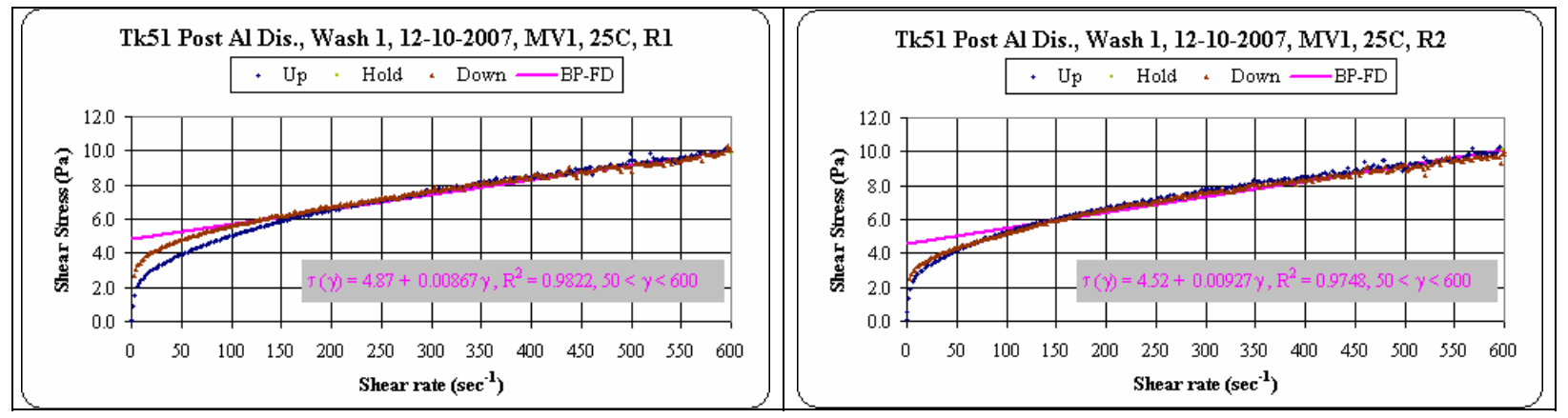

Figure C - 3 Tank 51, SRNL Post Aluminum Dissolution, Wash 1, Flow Curve 

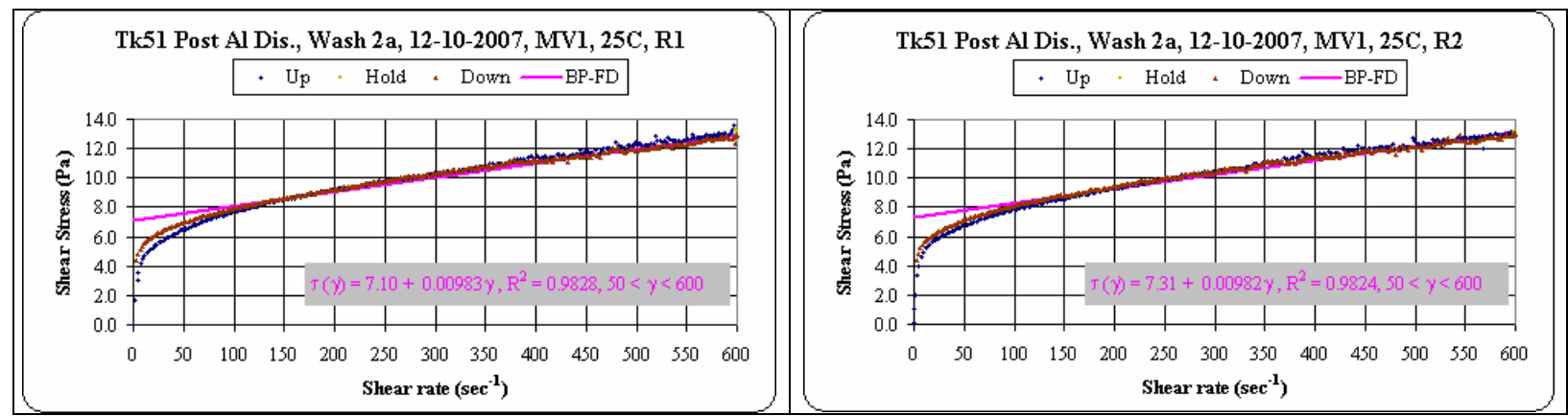

Figure C - 4 Tank 51, SRNL Post Aluminum Dissolution, Wash 2a, Flow Curve

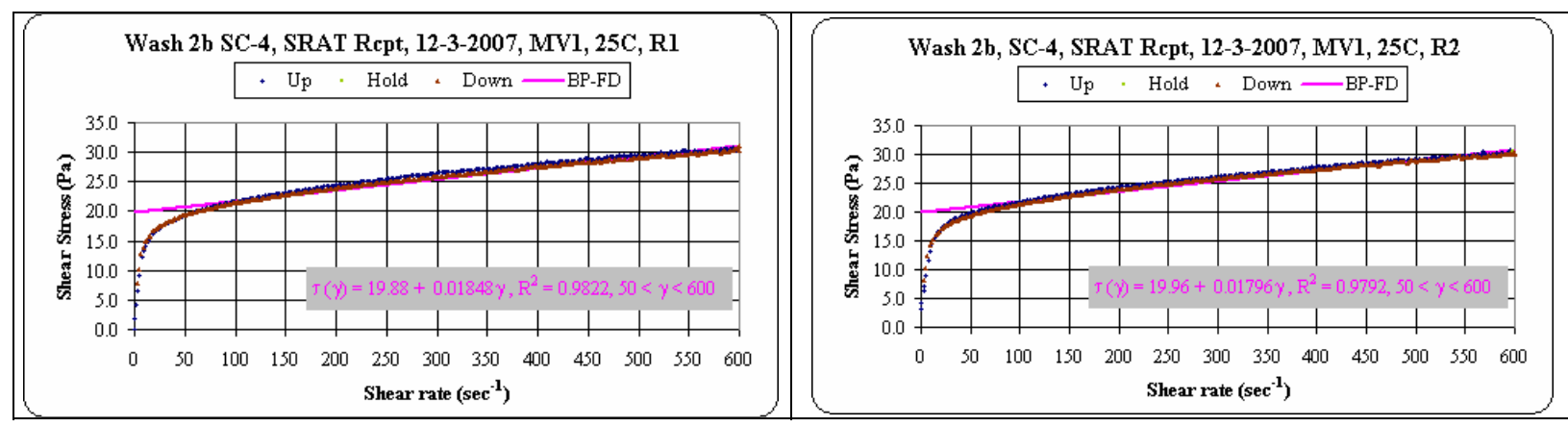

Figure C - 5 Tank 51, SRNL Post Aluminum Dissolution, Wash 2b SC-4 SRAT Rcpt, Flow Curve
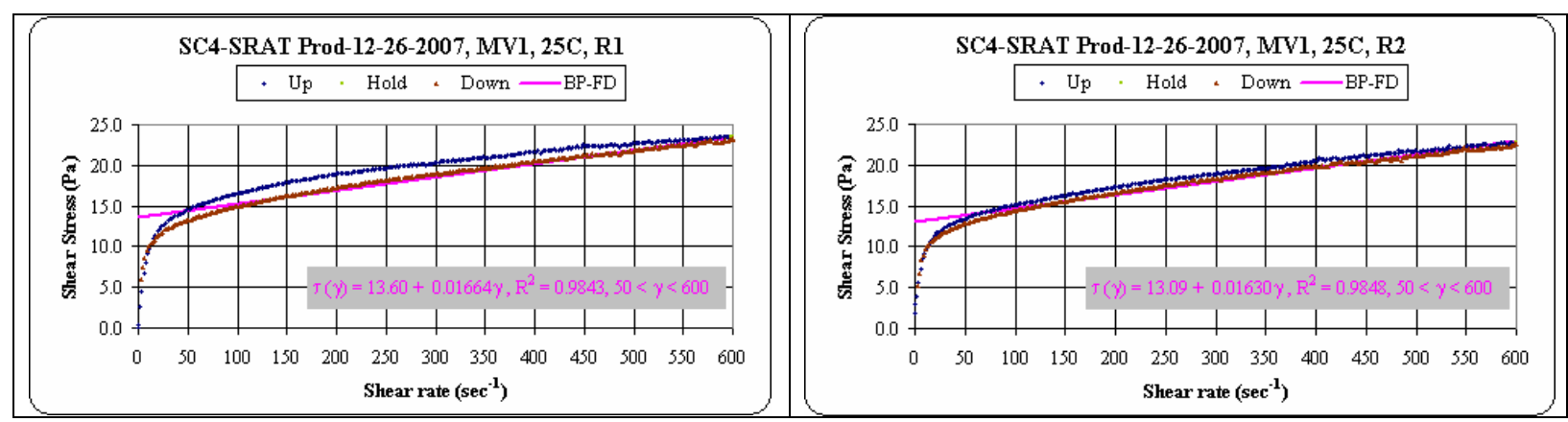

Figure C - 6 SRNL SC-4 SRAT Product, Flow Curve 
WSRC-STI-2008-00086

Revision 0
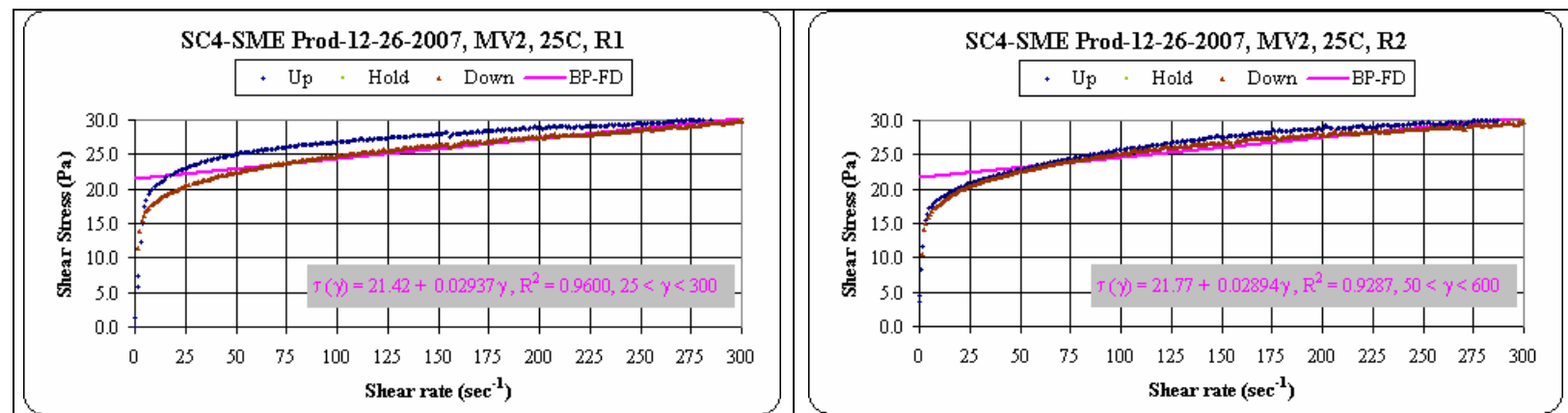

Figure C - 7 SRNL SC-4 SME Product, Flow Curve

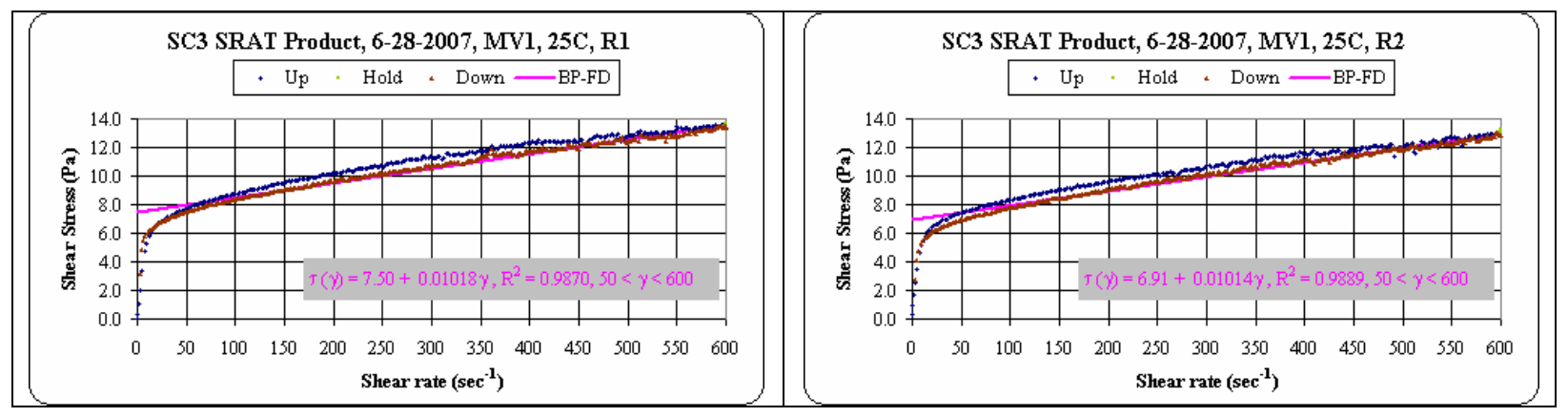

Figure C - 8 SRNL SC-3 SRAT Product, Flow Curve

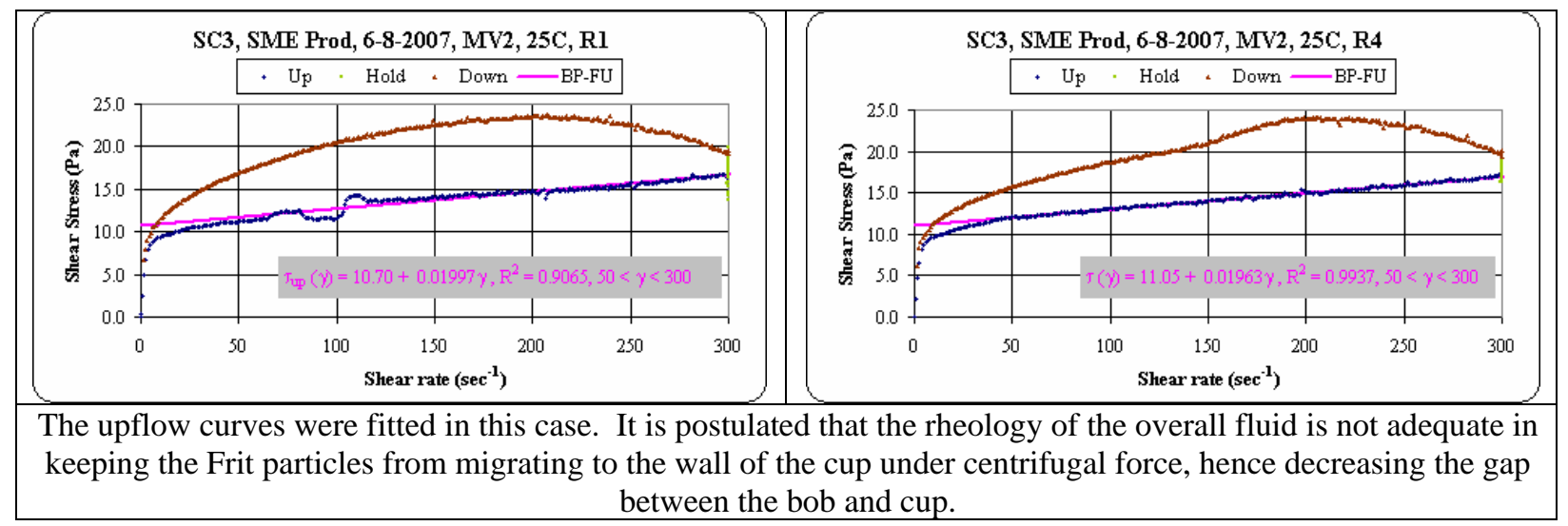

Figure C - 9 SRNL SC-3 SME Product, Flow Curve 


\section{APPENDIX D. HYDROGEN GENERATION FROM THE SIMULANT SRAT CYCLES SUPPORTING THE POST ALUMINUM DISSOLUTION CPC PROCESSING}

SB5-4 (115\%) and SB5-5 (130\%) Hydrogen Generation, Ib/hr DWPF 6000 gal DWPF Scale

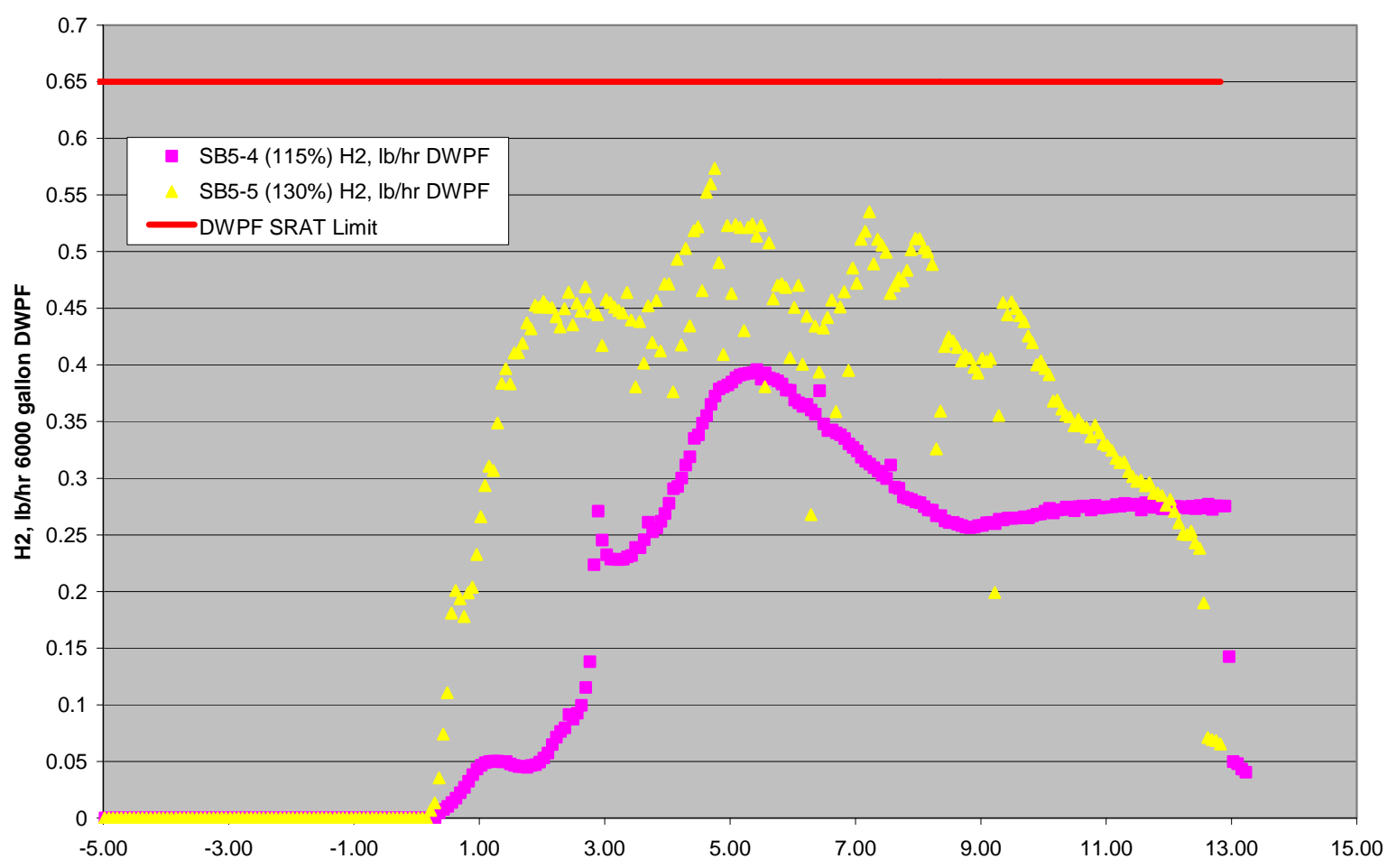

$\mathrm{x}$ axis is time relative to end of acid addition. 


\section{Distribution:}

J.E. Marra, 773-A

J.C. Grifin, 773-A

A.B. Barnes, 999-W

D.A. Crowley, 999-W

B.J. Giddings, 786-1A

C.C. Herman, 773-42A

C.J. Bannochie, 773-42A

M.J. Barnes, 773-A

N.E. Bibler, 773-A

J.M. Bricker, 704-27S

L.M. Chandler, 773-A

L.H. Connelly, 704-28S

B.A. Davis, 704-27S

R.E. Eibling, 999-W

H.H. Elder, 704-30S

T.B. Edwards, 999-W

T.L. Fellinger, 704-28S

S.D. Fink. 773-A

K.M. Fox, 999-W

J.M. Gillam, 766-H

B.A. Hamm, 766-H

J.R. Harbour, 773-42A

M.S. Hay, 773-42A

J.F. Iaukea, 704-30S

D.C. Koopman, 999-W

D.P. Lambert, 999-W

R.N. Mahannah, 704-28S

R.T. McNew, 704-27S

D.J. McCabe, 773-42A

J.E. Occhipinti, 704-S

J.M. Pareizs, 773-A

D.K. Peeler, 999-W

F.M. Pennebaker, 773-A

B.R. Pickenheim, 999-W

J.A. Pike, 703-H

T.M. Punch, 766-H

J.W. Ray, 704-S

S.H Reboul, 773-42A

H.B. Shah, 766-H

M.E. Smith, 999-W

M.E. Stone, 999-W

J. Stuberfield, 766-H

P.C. Suggs 704-S

W.D. Wilmarth, 773-42A 